Atmos. Chem. Phys., 18, 11885-11903, 2018

https://doi.org/10.5194/acp-18-11885-2018

(C) Author(s) 2018. This work is distributed under

the Creative Commons Attribution 4.0 License.

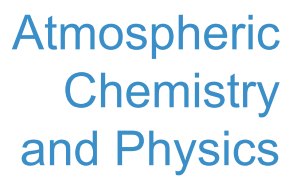

(c) (P)

\title{
Are EARLINET and AERONET climatologies consistent? The case of Thessaloniki, Greece
}

\author{
Nikolaos Siomos ${ }^{1}$, Dimitris S. Balis ${ }^{1}$, Kalliopi A. Voudouri ${ }^{1}$, Eleni Giannakaki ${ }^{2,4}$, Maria Filioglou ${ }^{1,2}$, \\ Vassilis Amiridis $^{3}$, Alexandros Papayannis ${ }^{5}$, and Konstantinos Fragkos ${ }^{6}$ \\ ${ }^{1}$ Laboratory of Atmospheric Physics, Physics Department, Aristotle University of Thessaloniki, Thessaloniki, Greece \\ ${ }^{2}$ Finnish Meteorological Institute, Atmos. Res. Center of Eastern Finland, Kuopio, Finland \\ ${ }^{3}$ Institute for Astronomy, Astrophysics, Space Applications and Remote Sensing, \\ National Observatory of Athens, Athens, Greece \\ ${ }^{4}$ Department of Environmental Physics and Meteorology, Faculty of Physics, University of Athens, Athens, Greece \\ ${ }^{5}$ National Technical University of Athens, Physics Department, Laser Remote Sensing Laboratory, Athens, Greece \\ ${ }^{6}$ National Institute of R\&D in Optoelectronics, Magurele, Romania
}

Correspondence: N. Siomos (nsiomos@ physics.auth.gr)

Received: 22 December 2017 - Discussion started: 13 February 2018

Revised: 6 July 2018 - Accepted: 17 July 2018 - Published: 21 August 2018

\begin{abstract}
In this study we investigate the climatological behavior of the aerosol optical properties over Thessaloniki during the years 2003-2017. For this purpose, measurements of two independent instruments, a lidar and a sunphotometer, were used. These two instruments represent two individual networks, the European Lidar Aerosol Network (EARLINET) and the Aerosol Robotic Network (AERONET). They include different measurement schedules. Fourteen years of lidar and sunphotometer measurements were analyzed, independently of each other, in order to obtain the annual cycles and trends of various optical and geometrical aerosol properties in the boundary layer, in the free troposphere, and for the whole atmospheric column. The analysis resulted in consistent statistically significant and decreasing trends of aerosol optical depth (AOD) at $355 \mathrm{~nm}$ of -23.2 and $-22.3 \%$ per decade in the study period over Thessaloniki for the EARLINET and the AERONET datasets, respectively. Therefore, the analysis indicates that the EARLINET sampling schedule can be quite effective in producing data that can be applied to long-term climatological studies. It is also shown that the observed decreasing trend is mainly attributed to changes in the aerosol load inside the boundary layer. Seasonal profiles of the most dominant aerosol mixture types observed over Thessaloniki have been generated from the lidar data. The higher values of the vertically resolved
\end{abstract}

extinction coefficient at $355 \mathrm{~nm}$ appear in summer, while the lower ones appear in winter. The dust component is more dominant in the free troposphere than in the boundary layer during summer. The biomass burning layers tend to arrive in the free troposphere during spring and summer. This kind of information can be quite useful for applications that require a priori aerosol profiles. For instance, they can be utilized in models that require aerosol climatological data as input, in the development of algorithms for satellite products, and also in passive remote-sensing techniques that require knowledge of the aerosol vertical distribution.

\section{Introduction}

The atmospheric aerosol load typically shows a significant spatial and temporal variability within the lower atmosphere (e.g., Hamill et al., 2016). This is related both to the plethora of aerosol emission sources near the ground and to the variable weather conditions that appear in the troposphere. Since transport is driven by the atmospheric conditions, the aerosol properties over a given location are expected to follow annual and climatological patterns just as the wind does (e.g., Takemura et al., 2002). Similar patterns can be observed in the emission sources as well (e.g., Stefan et al., 2013). As a mat- 
ter of fact, a lot of human activities that result in the emission of anthropogenic aerosols exhibit annual cycles (e.g., Yiquan et al., 2015). This is also true for the natural emissions that are usually driven by weather conditions (e.g., Israelevich et al., 2012). The knowledge of the climatological behavior of particles in the troposphere can be utilized in many different ways. Its applications can range from purely scientific, such as the validation of aerosol transportation and air quality models (e.g., Binietoglou et al., 2015; Siomos et al., 2017) and satellite instruments (e.g., Balis et al., 2016), to civilly oriented, for example the impact of the aerosol load on human health (e.g., Mauderly and Chow, 2008; Löndahl et al., 2010), airfare safety (e.g., Brenot et al., 2014), and agriculture (e.g., Gerstl and Zardecki, 1982).

In order to conduct a climatology study, long-term scheduled measurements are required. In situ techniques focus on measurements of the aerosol properties close to the ground. It is both challenging and costly to acquire those measurements at high altitudes (i.e., mounted on airplanes and unmanned aerial vehicles), especially on a routine basis. For those reasons, the application of remote-sensing techniques from ground-based instruments is usually preferred. Lidar systems are ideal when the vertical distribution is being investigated (e.g., Klett, 1981; She et al., 1992; Ansmann et al., 1992; Welton et al., 2001; Hirsikko et al., 2014). Passive remote-sensing instruments are also broadly used in order to examine the columnar aerosol properties (e.g., Dubovik and King, 2000; Hönninger et al., 2004; Schneider et al., 2008; Herman et al., 2017; López-Solano et al., 2018).

Previous climatological studies using Raman lidar measurements at Thessaloniki were conducted by Amiridis et al. (2005) and Giannakaki et al. (2010), covering the periods 2001-2004 and 2001-2007, respectively. These studies focus on the seasonal variability of various aerosol optical properties inside the planetary boundary layer (PBL) and in the free troposphere (FT), separately for the predominant aerosol mixtures. For example, Amiridis et al. (2005) have found a seasonal pattern in the columnar aerosol optical depth (AOD), with higher values occurring mainly in early spring and late summer due to an enhanced free-tropospheric contribution, while Giannakaki et al. (2010) observed larger optical depth values for Saharan dust and smoke particles. However, the limited number of years did not permit the calculation of long-term trends. On the other hand, Kazadzis et al. (2007) and Fountoulakis et al. (2016) analyzed longer datasets, based on spectral irradiance measurements for Thessaloniki, that allowed them to investigate the long-term variability and the annual cycles of the aerosol optical depth in the UV for Thessaloniki. They used retrievals of AOD from two different Brewer spectrophotometers in the periods 1997-2005 and 1994-2006. For instance, Kazadzis et al. (2007) detected a seasonal variation in the monthly means of AOD at $340 \mathrm{~nm}$ with maximum optical depth values in the summer months and minimum in wintertime, while Fountoulakis et al. (2016) detected a trend of AOD at $320 \mathrm{~nm}$ of $-0.09 \pm 0.01$ per decade. In their case, however, it was not possible to provide information on the aerosol vertical distribution due to the nature of their instrumentation.

In this study we have investigated the climatological behavior of the aerosol optical and geometrical properties over Thessaloniki during the period 1 June 2003 to 31 May 2017, which, hereafter, will be referred to as "period 2003-2017". We have used the measurements of two independent datasets that represent two individual networks with different measurement schedules and techniques.

The first dataset includes measurements performed with a Raman lidar in Thessaloniki, Greece $\left(40.63^{\circ} \mathrm{N}, 22.96^{\circ} \mathrm{E}\right)$. This instrument is part of the European Aerosol Lidar Network (EARLINET). The EARLINET schedule for climatological measurements is adopted (e.g., Giannakaki et al., 2010), and measurements are systematically performed every Monday morning, preferably close to 12:00 UTC, and every Monday and Thursday evening, preferably after sunset, resulting in 302 days with measurements. After the CALIPSO mission in 2006, lidar measurements have also been performed during the CALIPSO overpasses (Winker et al., 2009; Pappalardo et al., 2010), resulting in 73 additional days with lidar data. Finally, depending on the station's needs, measurements are performed during special events, resulting in 143 additional days of data. The full dataset includes 518 days when at least one lidar profile is available. The second dataset includes data measured with a Cimel sunphotometer that is part of the Aerosol Robotic Network (AERONET). Measurements are automatically performed every $15 \mathrm{~min}$ or less, depending on the sun's zenith angle (Holben et al., 1998; Dubovik and King, 2000). By using these data, the long-term variability, the annual cycles, and trends of various optical and geometrical properties have been examined. Furthermore, we have separately investigated the climatological behavior of aerosols in the PBL and in the FT. Taking into account the different sampling rate of the two datasets and the different measurement techniques, the aim of our study was to ultimately reach a more solid conclusion regarding the capability of the two datasets to produce consistent climatological patterns when analyzed independently of each other. It is not our intent to perform a point-by-point comparison of measurements between the two techniques that are coincident in time. However, the uncertainties involved in producing the climatological datasets are discussed in Sect. 4.5.

\section{Instrumentation and tools}

\subsection{The lidar system}

The setup of the lidar system is discussed in this section. It belongs to the Laboratory of Atmospheric Physics that is located in the Physics Department of the Aristotle University of Thessaloniki $\left(40.63^{\circ} \mathrm{N}, 22.96^{\circ} \mathrm{E}\right)$ at an elevation of $50 \mathrm{~m}$. 
The first $(1064 \mathrm{~nm})$, second $(532 \mathrm{~nm})$, and third harmonic $(355 \mathrm{~nm})$ frequency of a compact, pulsed Nd:YAG laser are emitted with a $10 \mathrm{~Hz}$ repetition rate (more technical details can be found on Amiridis et al., 2005). The radiation from the atmospheric backscattering of the laser beam is collected with a $500 \mathrm{~mm}$ diameter telescope. The lidar has been part of EARLINET (Schneider et al., 2000; Pappalardo et al., 2014) since 2000. The original setup of the Raman lidar in 2000 included two elastic channels at 355 and $532 \mathrm{~nm}$ and a Raman channel at $387 \mathrm{~nm}$ (Amiridis et al., 2005). More channels were added later on. An additional Raman channel at $607 \mathrm{~nm}$ was added in 2008. Another elastic channel at $1064 \mathrm{~nm}$ plus one parallel and one cross-polarization channel at $532 \mathrm{~nm}$ were added in 2012 (Siomos et al., 2017). The final products, which derived from the raw lidar data processing (see Sect. 3.2), are the aerosol backscatter coefficient at 355,532 , and $1064 \mathrm{~nm}$ and the aerosol extinction coefficient at 355 and $532 \mathrm{~nm}$. The dataset included in this study covers the period 2003-2017 in order to be chronologically consistent with the sunphotometer dataset (see Sect. 2.2). All of the aforementioned products are publicly available in the EARLINET database (https://www.earlinet.org).

\subsection{Lidar overlap function}

A common source of uncertainty when dealing with lidar data is the system's overlap function, which determines the altitude above which a profile contains trustworthy values. For simplicity we will refer to this altitude as "starting height" in the paper. In our analysis, if a correction is not available for the system's overlap, the starting height is set to the full overlap height. This is true for all our daytime elastic backscatter profiles and the nighttime elastic backscatter $532 \mathrm{~nm}$ profiles prior to 2008 . The starting height is below $1.5 \mathrm{~km}$ for $86 \%$ of those profiles. The Raman extinction profiles are much more sensitive to the overlap effect (see Sect. 3.2). The method of Wandinger and Ansmann (2002) is applied if Raman profiles are available, and the overlap function is calculated and applied individually per Raman case. The correction is also applied to the nighttime elastic backscatter at $1064 \mathrm{~nm}$ that became available in 2012. The calculated overlap function can be trusted for values greater than 0.7 (Amiridis et al., 2005). In those profiles, the starting height is set to the altitude where the overlap equals 0.7 , resulting in values below $1.5 \mathrm{~km}$ for $90 \%$ of the overlapcorrected profiles. For the calculation of the columnar properties, a constant profile is assumed from the starting height to the ground. This introduces uncertainties in the calculation of the AOD. The impact of these uncertainties in the climatological analysis will be discussed in Sect. 4.5.

\subsection{The sunphotometer}

The Cimel multiband sun-sky photometer was installed in Thessaloniki in 2003 as part of the AERONET global net- work. It is located at the same altitude as the lidar system. The distance between them is less than $50 \mathrm{~m}$. It performs direct solar irradiance and sky radiance measurements at 340, $380,440,500,670,870$, and $1020 \mathrm{~nm}$ automatically during the day. The AERONET inversion algorithms (Dubovik and King, 2000; Dubovik et al., 2006) are applied automatically to the raw data. The products are publicly available online (https://aeronet.gsfc.nasa.gov). The Level 2.0 Version 3 AOD values at $440,675,870$, and $1020 \mathrm{~nm}$ in the period 2003 2017 were used in this study in order to take advantage of the longer time series since the 340 and $380 \mathrm{~nm}$ channels were added later, in 2005, and were also missing for the period 2008-2011 due to changes of the instrument. A conversion technique is applied in order to calculate the sunphotometer AOD at lidar-compatible wavelengths. It is discussed in Sect. 3. Details on the instrument and the AERONET infrastructure are included in Holben et al. (1998).

\section{Methodology}

The pre-processing required in order to obtain the final climatological products is discussed in this section. The full dataset is applied for the calculation of the aerosol geometrical properties. The lidar dataset applied for the calculation of the aerosol optical properties is a subset that includes the nighttime aerosol extinction profiles at $355 \mathrm{~nm}$ and the corresponding aerosol backscatter profiles at 355 and $532 \mathrm{~nm}$ (Sect. 2.1), while the sunphotometer dataset contains AOD data at $440,675,870$, and $1020 \mathrm{~nm}$ (Sect. 2.2).

Further processing is required in order to get some structural elements from the lidar profiles. These structural elements are often referred to as geometrical properties. In our analysis, we have calculated the boundary layer height and the first major lofted layer base, top, and center of mass height. With this information the AOD within the PBL and the FT can be distinguished. The AOD at $355 \mathrm{~nm}$ is calculated from the integration of the lidar extinction profiles. The integrated backscatter coefficients at 355 and $532 \mathrm{~nm}$ are also obtained from the EARLINET dataset. Finally, some intensive optical products that are characteristic of the aerosol type and derive from the backscatter and the extinction profiles have been calculated. This includes the extinction-tobackscatter ratio, often referred to as the lidar ratio (LR), at $355 \mathrm{~nm}$ and the backscatter-related Ångström exponent (BAE) in the spectral region $355-532 \mathrm{~nm}$. The former depends mostly on the absorption and scattering aerosol properties, while the latter depends mainly on the aerosol size distribution. The analysis covers both the profile and the columnar versions of these products.

An overview of the EARLINET dataset is provided in Sect. 3.2. The pre-processing required in order to calculate the geometrical optical properties from the lidar profiles is described in Sects. 3.3 and 3.4. 


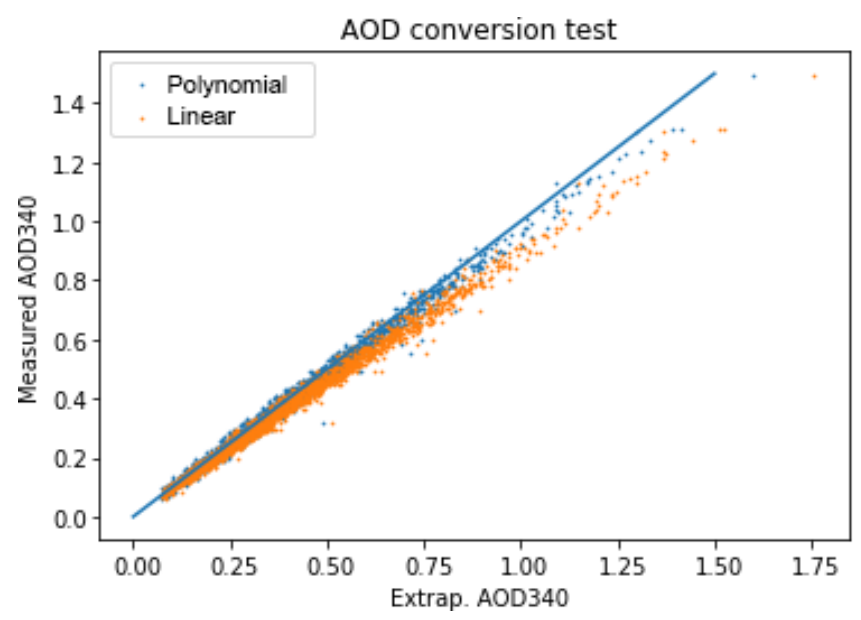

Figure 1. Scatterplot of the measured sunphotometer AOD at $340 \mathrm{~nm}$ against the extrapolated AOD at $340 \mathrm{~nm}$. Two methods of extrapolation are presented. The "linear" approach assumes a linear behavior of the logarithm of the AOD in the spectral region 340$1020 \mathrm{~nm}$, while the polynomial approach assumes a second-order polynomial behavior. The unity line is also included.

\subsection{Sunphotometer pre-processing}

It is necessary to make the sunphotometer optical depth compatible with the lidar optical depth at $355 \mathrm{~nm}$. An extrapolation method is applied (Soni et al., 2011) in order to obtain the AOD at $355 \mathrm{~nm}$ from the sunphotometer data. This method assumes a second-order polynomial relationship for the logarithm of the AOD in the spectral region 340$1020 \mathrm{~nm}$. The constant Ångström approach is instead equivalent to a linear fit to the logarithm of the AOD. The secondorder polynomial is calculated by fitting the sunphotometer AOD values at $440,675,870$, and $1020 \mathrm{~nm}$ on a logarithmic scale. Cases with too-low AOD $440 \mathrm{~nm}$ values, below 0.05 , and cases where the polynomial is ill-fitted are excluded. The AOD at $355 \mathrm{~nm}$ is then extrapolated from the polynomial, assuming that it is also valid in the UV region. The validity of the conversion is tested with the sunphotometer AOD at $340 \mathrm{~nm}$ for the periods when both were available. In Fig. 1, the extrapolated AOD at $340 \mathrm{~nm}$, using both the second-order polynomial and the linear fit methods, is compared with the measured AOD at $340 \mathrm{~nm}$. The "linear" method tends to systematically produce higher extrapolated AOD, especially for the cases with high AOD. This behavior is also present in the "polynomial" approach, but it is much less pronounced. In this case, the absolute bias is below 0.035 for $90 \%$ of the cases. The sunphotometer uncertainty is 0.02 and should be even higher for the UV (Kazadzis et al., 2016). Consequently, this conversion ensures that the error introduced by the AOD extrapolation is typically close to the sunphotometer uncertainty.

\subsection{Dataset overview}

Many techniques and methods have been developed for lidar signal pre-processing and inversions (e.g., Klett, 1981; Fernald, 1984; Ansmann et al., 1992; Lopatin et al., 2013; Chaikovsky et al., 2016). In order to ensure qualitative and consistent data processing within the EARLINET network, algorithm intercomparison campaigns have been organized (Matthias et al., 2004; Pappalardo et al., 2004; Böckmann et al., 2004). These campaigns aimed to establish the standard methods that can be utilized by all the stations. Additionally, some quality standards have been established, in order to make the lidar products of the different systems comparable and to be able to provide quality-assured datasets of network products (Freudenthaler et al., 2018).

Concerning the time series under study, two different methods of processing are applied depending on the type of measurement. During the day, the data acquisition is limited to the signals that occur from the elastic scattering of the laser beam by the air molecules and the atmospheric aerosol. The Klett-Fernald-Sasano (KFS) inversion is applied (Klett, 1981; Fernald, 1984; Sasano and Nakane, 1984), and the backscatter coefficient profiles are produced. A constant a priori climatological value of the lidar ratio has to be assumed in this method. The resulting uncertainties are discussed in depth by Böckmann et al. (2004) and can be as high as $50 \%$ if there is no information about the actual lidar ratio.

In the night, the vibrational Raman bands of the atmospheric nitrogen at 387 and $607 \mathrm{~nm}$ can be recorded. In this case, the Raman inversion (Ansmann et al., 1992) is applied. It allows the calculation of both the extinction and the backscatter profiles without any assumption regarding lidar ratio. Nevertheless, a constant a priori value of the Ångström exponent between the elastic and the Raman wavelength has to be assumed. The relative error introduced should be less than $4 \%$ (Ansmann et al., 1992). The technique described in Wandinger and Ansmann (2002) allows the calculation of the lidar system's overlap function from Raman measurements. The correction is applied individually to each Raman measurement. This is particularly important for the calculation of the extinction profiles. They are calculated using the inelastic signal height derivative (Ansmann et al., 1992). As a result, they are very sensitive to the system's overlap function.

A time-height cross section of the aerosol extinction coefficient at $355 \mathrm{~nm}$ for the period 2003-2017 is presented in Fig. 2. It gives an overview of the availability of the lidar measurements. The monthly mean values are produced using every available measurement. The long gaps in the years 2008 and 2011 of the time series are attributed to system upgrades. Some missing months also occur, especially during winter, when the weather conditions are not favorable for lidar measurements. The aerosol load seems to be significant only below $4 \mathrm{~km}$ in most cases. The highest extinction values are typically observed closer to the ground, as expected. This is attributed to the mixing mechanisms that take place near 


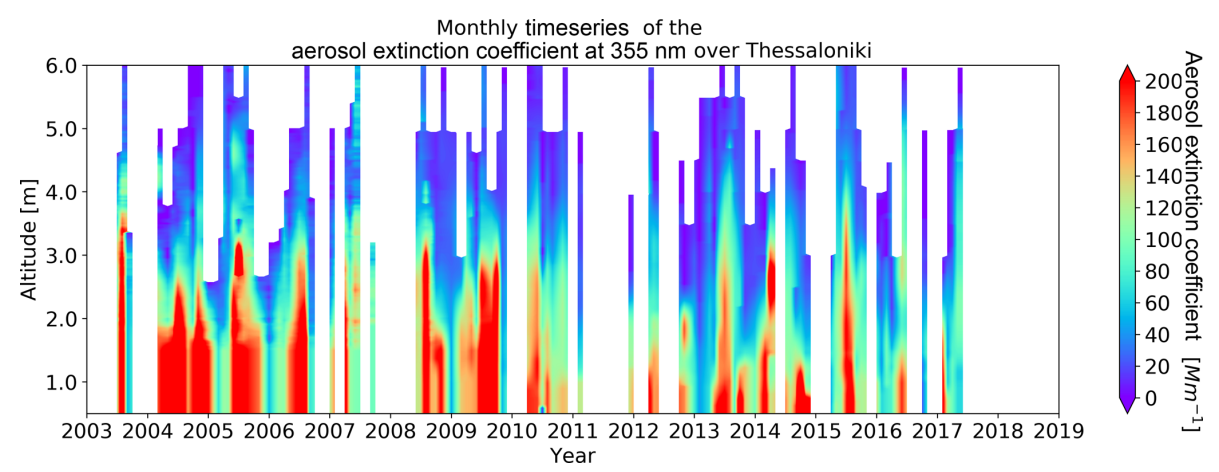

Figure 2. Time-height cross section of the monthly mean aerosol extinction coefficient at $355 \mathrm{~nm}$ in the period $2003-2017$.

the surface. Elevated layers can also be observed, especially in the summer months. Geometrical features that are representative of the vertical distribution of the aerosol load can be obtained from the lidar profiles. In Sect. 3.3 we discuss the algorithmic processes that are required in order to extract those features.

\subsection{Geometrical properties}

The aerosol geometrical properties carry information about the structure of lidar profiles. Examples are the boundary layer height and the boundaries of the lofted layers. They can be obtained from any lidar profile. As a result, the full lidar dataset presented in Sect. 2.1 has been applied for the calculations. Some lidar products, however, are more accurate to use than others. For example, the longer wavelengths typically magnify the differences in the vertical distribution of the aerosol load, resulting in layers that are easier to identify. Furthermore, the Raman inversion always results in profiles that are less structured for the extinction coefficients than the backscatter coefficients. This is the reason why we prioritize them in order to produce geometrical properties. The product with the highest potential to magnify the layer structure available is selected for each measurement. More specifically, the backscatter products are prioritized over the extinction products, and the longer wavelengths over the shorter ones.

\subsubsection{Boundary layer height detection}

Many methods have been proposed for the calculation of the PBL height from lidar data (e.g., Flamant et al., 1997; Menut et al., 1999; Brooks, 2003; Tomasi and Perrone, 2006; Haeffelin et al., 2012; Milroy et al., 2012; Bravo-Aranda et al., 2017). Our analysis is based on the method of Baars et al. (2008) that applies the wavelet covariance transform (WCT) to the raw lidar data in order to extract geometrical features such as the PBL height and the cloud boundaries. In our case, we want to apply this method to the database products instead. The WCT transformation has also been applied successfully in the past on other lidar products. Siomos et al. (2017), for example, use an adaptation of the WCT method and calculate the geometrical features from the aerosol concentration profiles. The transform is provided by Eq. (1):

$W(\alpha, z)=\frac{1}{\alpha}\left(\int_{z-\frac{\alpha}{2}}^{z} F(r) \mathrm{d} r-\int_{z}^{z+\frac{\alpha}{2}} F(r) \mathrm{d} r\right)$,

where $F$ is the product profile which the transform is being applied to, $W$ is the result of the transformation, $z$ and $r$ are the altitude, and $\alpha$ is the dilation. A dilation of $0.4 \mathrm{~km}$ is used for the PBL height calculations, similar to Baars et al. (2008). Additionally, an upper limit is necessary so that the top of elevated layers is not misidentified as the PBL (Baars et al., 2008). We use an upper limit of $4.2 \mathrm{~km}$ to be consistent with previous studies over the area (Georgoulias et al., 2009).

The boundary layer is evolving during the day and reaches its maximum height at 12:00 local solar time. Consequently, as far as the daytime measurements are concerned, we preferred to use only measurements performed between 10:00 and 13:00 UTC. After sunset, the boundary layer collapses fast, and the stable boundary layer (SBL) forms typically less than $0.5 \mathrm{~km}$ above the ground (Garratt, 1992; Mehta et al., 2017). The mixing mechanisms are restricted within this layer during the night. Unfortunately, the SBL cannot be detected with the lidar of Thessaloniki since most of the profiles start above $0.8 \mathrm{~km}$. Despite that, the particles that have been transported by the turbulence during the day take more time to settle, forming the so-called residual layer. As far as the aerosols are considered, this layer height bears many similarities to the daytime boundary layer height. We are particularly interested in this nighttime layer since the aerosol extinction coefficient profiles are available only after sunset (see Sect. 3.2). Both for this reason and for reasons of simplification, in the next sections we will use the terms "daytime PBL" instead of daytime boundary layer and "nighttime PBL" instead of nighttime residual layer.

The upper boundary of the daytime and nighttime PBL was identified in approximately $99 \%$ of the cases. At this point it is necessary to mention that the PBL top is difficult to discern when large transported aerosol layers arrive and 
mix with local particles below $2 \mathrm{~km}$. In those cases, the PBL height can be either completely obscured or misidentified as the transported layer's upper boundary. Baars et al. (2008) present such an example. In one of their cases, an elevated dust layer complicated the retrieval of the PBL height. Additionally, due to hardware restrictions of the lidar instruments, such as the system's overlap function (Wandinger and Ansmann, 2002), near-ground values are typically not provided. As far as the system of Thessaloniki is concerned, most of the profiles begin above $0.8 \mathrm{~km}$. It is indeed quite rare to find profiles starting below $0.6 \mathrm{~km}$. This, however, could also result in false identification of the PBL top when it is located close to the profile's starting height. This is expected to affect more the winter months, when the PBL is expected to be lower in Thessaloniki (Georgoulias et al., 2009). On the other hand, the winter measurements correspond to less than $10 \%$ of the profiles that were used for the PBL analysis.

\subsubsection{Lofted layer height detection}

An adaptation of the previous method (Sect. 3.3.1) is applied on the lofted layers. Since this is a climatological study and the interest is not in the fine structure that individual profiles may exhibit, we decided to identify only the first three major lofted layers. For this reason, a dilation of $0.8 \mathrm{~km}$ has been used. Finally, the center of mass is calculated based on Eq. (2), in which COM is the center of mass; $z$ is the altitude; $F$ is the profile product that is used in order to obtain the geometrical properties; and $z_{b}$ and $z_{t}$ are the layer's lower and upper boundaries, respectively.

$\mathrm{COM}=\frac{\int_{z_{b}}^{z_{t}} z \cdot F(z) \cdot \mathrm{d} z}{\int_{z_{b}}^{z_{t}} F(z) \cdot \mathrm{d} z}$

The first major layer was present in $48 \%$ of the profiles, while only $6 \%$ exhibited a second layer, and far fewer a third layer. This is not surprising considering the large dilation value. A climatological analysis requires a sufficient number of data. This is the reason why we decided to exclude the second and third major layers from the analysis.

The results are presented in Sect. 4.1. In Sect. 3.4, the processes that took place in order to obtain additional optical products from the ones already available are discussed.

\subsection{Optical properties}

A subset of the full lidar dataset was utilized for the analysis of the aerosol optical properties, which includes the nighttime aerosol extinction profiles at $355 \mathrm{~nm}$ and the nighttime aerosol backscatter profiles at $355 \mathrm{~nm}$ (Raman inversion) and $532 \mathrm{~nm}$ (Klett inversion). We excluded the daytime backscatter profiles in order to be consistent with the extinction climatology, since the extinction profiles are only available during nighttime. The LR (Eq. 3) at $355 \mathrm{~nm}$ and the BAE (Eq. 4) in the spectral range $355-532 \mathrm{~nm}$ can be calculated from the initial products. The lidar ratio is produced solely from Raman profiles, whereas the BAE at $355-532 \mathrm{~nm}$ is calculated both from Raman profiles, at $355 \mathrm{~nm}$, and from Klett profiles, at $532 \mathrm{~nm}$ (see Sect. 3.2). Both of these intensive properties are widely used because they are independent of the aerosol concentration, thus carrying information about the aerosol type and size. The respective formulas are provided in Eqs. (3) and (4), where $\lambda$ is the wavelength, $z$ is the height, $a$ is the aerosol extinction coefficient, and $b$ is the aerosol backscatter coefficient.

$\operatorname{LR}(\lambda, z)=\frac{a(\lambda, z)}{b(\lambda, z)}$
$\operatorname{BAE}_{\lambda 1-\lambda 2}(z)=-\frac{\ln \left(\frac{b\left(\lambda_{2}, z\right)}{b\left(\lambda_{1}, z\right)}\right)}{\ln \left(\frac{\lambda_{2}}{\lambda_{1}}\right)}$

Furthermore, some columnar products can be easily obtained from the profiles. The AOD and the mean columnar extinction at $355 \mathrm{~nm}$, as well as the integrated backscatter (INTB) and the mean columnar backscatter at 355 and $532 \mathrm{~nm}$ are calculated first. Then, the columnar lidar ratio at $355 \mathrm{~nm}$ and the BAE at $355-532 \mathrm{~nm}$, are produced from the mean extinction and backscatter values. Finally, the PBL top height (see Sect. 3.3) is used in order to separate the boundary layer and the free troposphere. After this, the aforementioned columnar products can also be separately calculated inside these two atmospheric regions.

\subsection{Data filtering and averaging}

This study is focused on climatological cycles and trends. The occurrence of random rare events that greatly deviate from the standard behavior within a given time range can affect the representability of the monthly and seasonal averages. Consequently, a filter that excludes such extreme events is applied on all optical products. For each product population, the upper and lower quartiles are produced for each month. Values that exceed the upper and lower quartiles by more than 1.5 times the interquartile range are excluded sequentially, one at a time, until there are no more outliers. Given, for instance, a normally distributed population, this filter would apply to the values that exceed approximately $\pm 2.7 \sigma$, which corresponds to $0.7 \%$ of the values. This applies to all the products described in Sects. 3.3 and 3.4. The backscatter and extinction profiles are filtered out based on their columnar versions, that is, the total AOD and the total integrated backscatter, respectively. The filtering is applied to the daily averages of both the lidar and the sunphotometer datasets. Ultimately, the purpose of this process is to eliminate the effect of the extremes in the monthly and seasonal averaging.

In order to calculate the monthly and seasonal (DJF, MAM, JJA, SON) mean values from the filtered products, the daily means are calculated first. Then the monthly means for each year are calculated by averaging the daily means, and the seasonal means are produced by averaging the monthly 

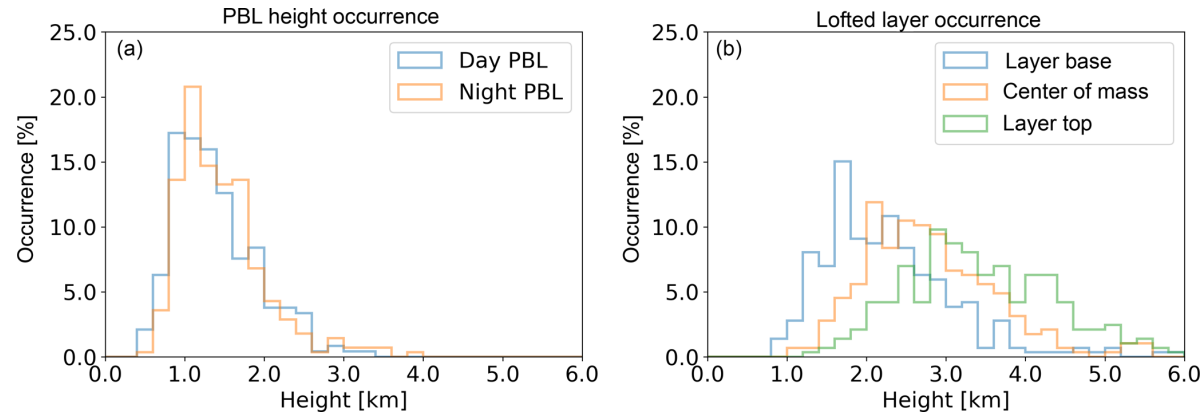

Figure 3. Histograms of the daytime and nighttime PBL top (a) and the first lofted layer base, center of mass, and top height distributions (b). The height classes range is set to $200 \mathrm{~m}$.

Table 1. Metrics of the aerosol geometrical properties.

\begin{tabular}{lrrrrrr}
\hline & Median & $\begin{array}{r}\text { Upper } \\
\text { quartile } \\
(75 \%)\end{array}$ & $\begin{array}{r}\text { Lower } \\
\text { quartile } \\
(25 \%)\end{array}$ & $\begin{array}{r}\text { Interquartile } \\
\text { range }\end{array}$ & $\begin{array}{r}\text { Upper } \\
\text { whisker }\end{array}$ & $\begin{array}{r}\text { Lower } \\
\text { whisker }\end{array}$ \\
\hline Day PBL & 1.22 & 1.62 & 0.98 & 0.64 & 2.51 & 0.74 \\
Night PBL & 1.25 & 1.72 & 0.96 & 0.75 & 2.78 & 0.71 \\
Layer base & 1.86 & 2.55 & 1.61 & 0.94 & 3.92 & 0.98 \\
Center of mass & 2.49 & 2.99 & 2.03 & 0.96 & 4.20 & 1.35 \\
Layer top & 3.14 & 3.74 & 2.49 & 1.25 & 5.03 & 1.79 \\
Thickness & 0.91 & 1.47 & 0.69 & 0.78 & 2.55 & 0.33 \\
\hline
\end{tabular}

mean values. For the EARLINET dataset, every available nighttime extinction profile at $355 \mathrm{~nm}$ and every nighttime backscatter profile at 355 and $532 \mathrm{~nm}$ (Sect. 3.4) are used. For the AERONET dataset, however, a limit of at least 10 daily mean values per month and at least 2 out of 3 monthly values per season was set in order to ensure that the averages are representative enough. We have to clarify here that the aim of this study is not to make a point-by-point comparison of the two datasets but to compare two independently estimated climatologies. In all cases, a limit of at least 5 years of monthly or seasonal averages per annual value is set for the annual cycles and seasonal profiles. This limit is empirical. Its purpose is to increase the representativity of the annual cycle without losing too many data points. Missing months or missing parts of the profile in Figs. 4 and 5 occur from this particular filter.

\section{Results and discussion}

The results of the climatological analysis of the optical and geometrical aerosol properties in Thessaloniki are presented in this section. The layer analysis of Sect. 3.3 is displayed and discussed in Sect. 4.1, while Sects. 4.2 and 4.3 include information on the seasonal response of all the columnar and profile products under study, respectively. Finally, the longterm trends of the two AOD databases are presented and discussed in Sect. 4.4.

\subsection{Layer analysis}

In this section the distributions of the layer features are examined. Figure 3 on the left contains the results displayed in histograms for the daytime and nighttime PBL top height, while Table 1 contains some metrics of the distributions. As was mentioned in Sect. 3.3.1, the daytime PBL corresponds to the available measurements between 10:00 and 13:00 UTC, while the nighttime PBL corresponds to all the available measurements after sunset. The daytime boundary layer and nighttime residual layer top are identified in $99 \%$ of the observations. The two distributions are similar, with median values around $1.2 \mathrm{~km}$. According to Table 1, the median difference is quite small, less than $0.1 \mathrm{~km}$. As mentioned in Sect. 3.3.1, the SBL is undetectable with the lidar system since it is so close to the ground. There is a peak at $1.1 \mathrm{~km}$ which is more pronounced for the nighttime PBL distribution. Furthermore, the majority (more than $50 \%$ ) of the cases exhibit PBL values between 0.9 and $1.8 \mathrm{~km}$. It is important to mention that the PBL top could be misidentified when the real PBL top is located below $0.8 \mathrm{~km}$ because, as mentioned in Sect. 3.3.1, the starting height of the profiles is typically above that height. This should mainly affect the measurements in winter, when the PBL top is expected to appear closer to the ground.

The results regarding the lofted layer are presented in Fig. 3 on the right. The upper and lower boundary and the center of mass distributions are displayed in histograms. All 
three of them are flatter than the PBL distribution, as the frequency never exceeds $15 \%$ in any height class. The maximum values appear at $1.7,2.1$, and $3.1 \mathrm{~km}$, and the median values appear at $1.86 \mathrm{~km}, 2.49$, and 3.14 for the base, center of mass, and top, respectively. The layer thickness ranges between 0.69 and $1.47 \mathrm{~km}$ for $50 \%$ of the cases. More information on the distributions is included in Table 1. As stated in Sect. 3.3.2, the lofted layer was present in $48 \%$ of the profiles. The seasonal analysis of the geometrical parameters displayed here is presented in Sect. 4.2 along with the various retrievals from lidar data.

\subsection{Seasonal cycles - columnar products}

In this section the optical and geometrical properties are analyzed in order to detect seasonalities in their annual cycle. The extrapolated AOD at $355 \mathrm{~nm}$ from the AERONET dataset is also included. The results of the columnar optical products and the geometrical products are displayed in monthly boxplots (Fig. 4), while the results of the profile optical products are exhibited in the form of seasonal average profiles (see Sect. 4.3). The boxplots are constructed using the monthly average population. This is the reason why some outliers occur in Fig. 4 despite the application of the filtering process which has been applied to the initial and daily averages per month mentioned in Sect. 3.5. The annual monthly averages are also included in Fig. 4 (dots).

\subsubsection{Aerosol optical depth}

The results from the analysis of AOD at $355 \mathrm{~nm}$ are displayed in Figs. 4a and 3b. The AERONET dataset shows an annual cycle with the maximum annual mean values around 0.5 for July and August and the minimum values close to 0.25 in the winter months (Fig. 4a). A small secondary maximum appears at 0.4 in April. The EARLINET dataset shows a consistent annual cycle with the AERONET dataset. The Pearson correlation coefficient between the two annual cycles is 0.84, which is considered high (e.g., Lolli et al., 2013). The annual mean lidar AOD values range from 0.2 in January to 0.65 in August. Higher lidar values are clearly observed during summer. Furthermore, the lidar values are more broadly distributed. They always exhibit longer interquartile ranges, especially in April and the summer months. This probably occurs because the lidar sampling rate is much more sparse than the sunphotometer sampling rate. February and December not being included in the cloudy-weather conditions in the winter resulted in lidar data availability which does not fulfill the criteria mentioned in Sect. 3.5. Apart form cloudy conditions, due to hardware limitations, it is not possible for the lidar system to operate during days with strong winds. This is not the case for the sunphotometer and, therefore, could affect the results. For example, the AOD overestimation by approximately 0.1 of the lidar dataset during the summer months can be explained if days with strong winds in the summer are connected with lower aerosol load. Another probable explanation involves the uncertainties introduced due to the system's overlap in combination with the use of nighttime lidar measurements and daytime sunphotometer measurements. A systematic seasonal bias has been detected when isolating common sunphotometer and lidar cases and is discussed in Sect. 4.5.1. It equals 0.13 during summer, corresponding to higher lidar $\mathrm{AOD}$, and -0.15 during winter, corresponding to lower lidar AOD. Consequently, the summer and winter AOD differences observed in Fig. 4a could be attributed to such issues.

The AOD cycle in the PBL and in the FT is presented in Fig. 4b. The contribution from the free troposphere seems to be comparable to and even higher than the PBL contribution during April and the summer months. This is probably attributed to transported aerosols during summer and spring in the FT (see Sect. 4.2.2.4). The other months, especially March, exhibit a lower FT contribution.

\subsubsection{Lidar ratio and backscatter-related Ångström}

As far as the lidar ratio at $355 \mathrm{~nm}$ and the BAE at $355-532 \mathrm{~nm}$ are concerned, they exhibit more complicated patterns, ranging from 45 to $70 \mathrm{sr}$ and 1.0 to 2.0 , respectively. The lidar ratio shows two peaks, one in the summer months and another one in November that probably extends to January (Fig. 4c). Unfortunately, this is not so clear since February and December are not included. The minimum values occur in the spring months and in the early autumn months. The BAE cycle, on the other hand, is relatively stable, fluctuating between 1.1 and 1.5 for most months. The minimum values, which indicate larger particles, appear in May at 0.9, while the maximum values, which indicate smaller particles, appear in January at 1.9. Since both the lidar ratio and the BAE depend mainly on the aerosol type and size and not on the concentration, their variability should be more sensitive to transported aerosol events. For example, the higher lidar ratio and BAE values observed in the summer months are indicative of mixing with biomass burning layers. On the other hand, smaller BAE values accompanied by smaller lidar ratio values could be the result of a stronger sea salt or dust component. The optical properties of the cases that are affected by layers of transported aerosol and their climatological behavior are presented and discussed in Sect. 4.3.

\subsubsection{Boundary layer and first lofted layer}

The PBL height and the lofted layer center of mass cycles are presented in Fig. 3e and f, respectively. Looking at the PBL height, the maximum mean values, around $1.5 \mathrm{~km}$, appear from May to September. The minimum values, close to $1.1 \mathrm{~km}$, occur in March and December. In general, the PBL seems to be higher in the warm months (May to September) and lower in the cold months (November to March), as expected (Georgoulias et al., 2009), with the exception 

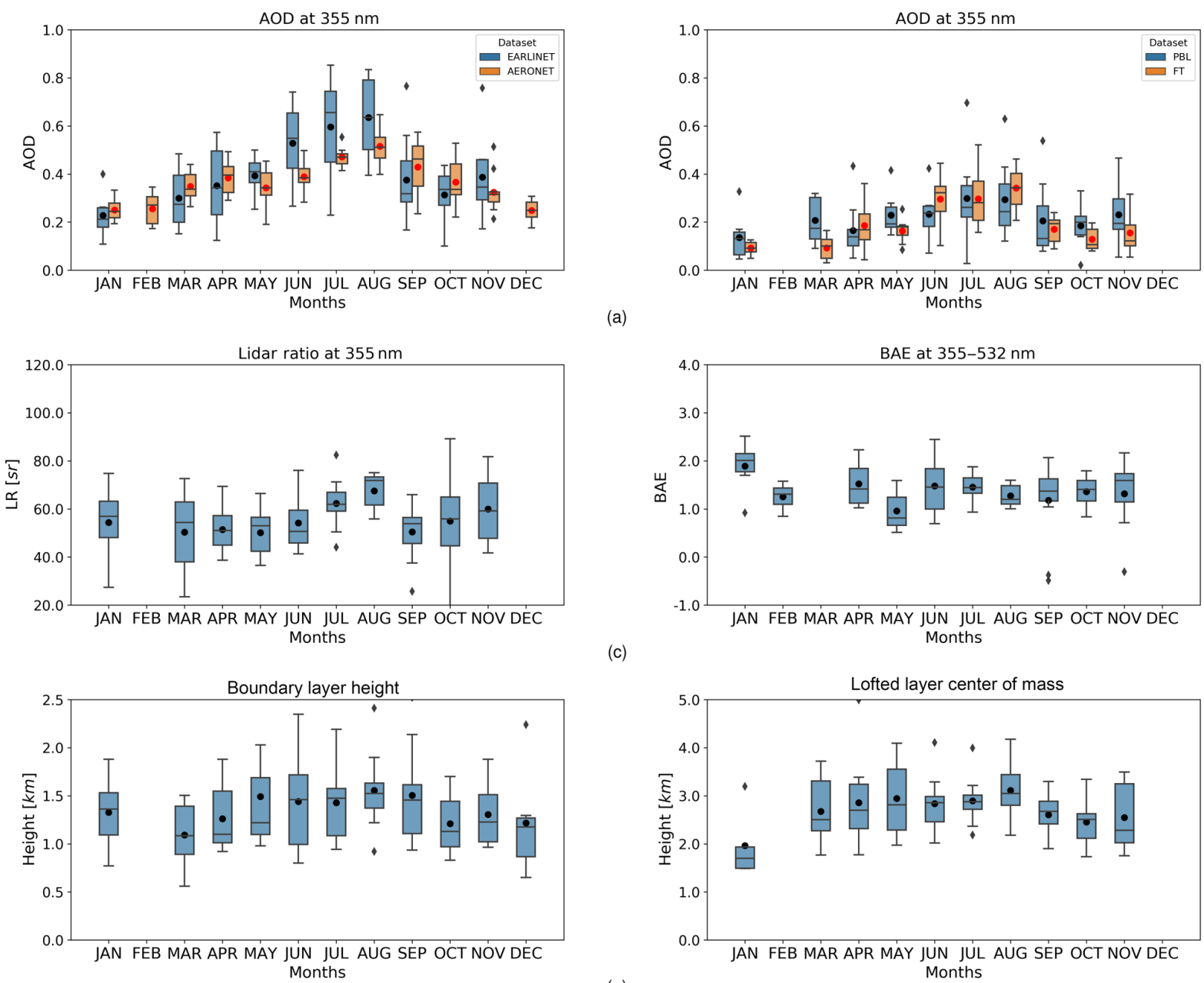

(c)

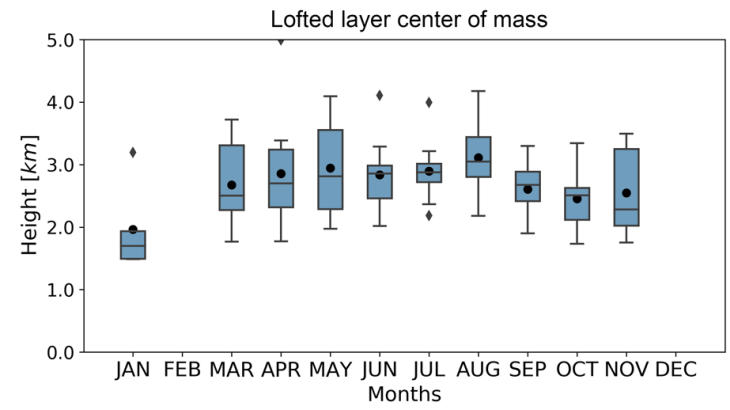

(b)

Figure 4. The annual cycle of the monthly mean columnar products. The AOD at $355 \mathrm{~nm}$ not only in the whole column (a) but also in the PBL and the FT (b), the mean lidar ratio at $355 \mathrm{~nm}$ (c), the mean BAE at 355-532 nm (d), the mean PBL height (e), and the mean lofted layer center of mass (f) are included in this figure. The AERONET mean AOD at $355 \mathrm{~nm}$ is also displayed in (a). In our analysis, the boxplot whiskers correspond to the most distant value encountered within 1.5 times the interquartile range above the upper and lower quartiles.

of January. This could be attributed to the difficulties that the lidar system faces below $800 \mathrm{~m}$, which were discussed in Sects. 2.2 and 3.3.1. Additionally, it was mentioned above that the lidar system usually operates under cloud-free conditions. In winter, this could result in a sampling that favors the presence of high-pressure systems and consequently higher PBL top height values. The missing point in February just makes it more difficult to draw any firm conclusions on this. The lofted layer is higher from February to September, with two peaks in May and August, probably due to dust and biomass burning layers that arrive in the FT. The lowest values appear in January and December.

\subsection{Seasonal cycles - profile products}

In this section, the seasonal profiles of the extinction coefficient at $355 \mathrm{~nm}$, the lidar ratio at $355 \mathrm{~nm}$, and the BAE at $355-532 \mathrm{~nm}$ are discussed. The results are presented in
Fig. 5 and in Tables 2, 3, and 4. The seasonality of each product is also analyzed in the boundary layer and the free troposphere per mixture type. These results are presented in tables. Four categories are included. The category "all" corresponds to the whole dataset for the optical properties (see Sect. 3.4). The categories "dust mixtures" and "biomass mixtures" correspond to the cases that contain at least one transported Saharan dust or biomass burning layer, respectively. The category "continental" (or "cont") contains the rest of the cases. This can include mixtures of soil dust, urban, agricultural, or maritime aerosol. The characterization of the dust and biomass burning measurements is already available in the EARLINET database, since it is performed manually per station before the measurements are uploaded. The process includes a back-trajectory analysis from the Hybrid Single Particle Lagrangian Integrated Trajectory Model (HYSPLIT) per layer. The biomass burning activity 


\section{Seasonal mean optical properties profiles for Thessaloniki}

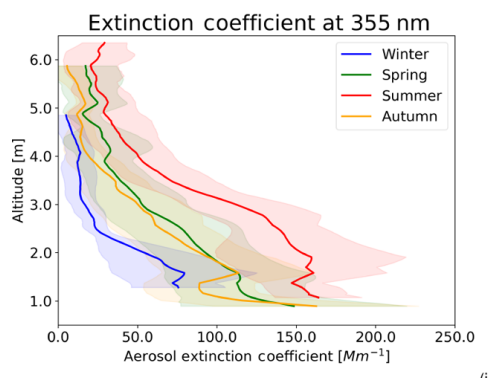

(i.a)

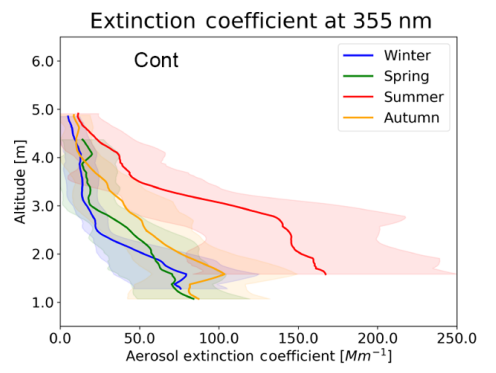

(ii.a)

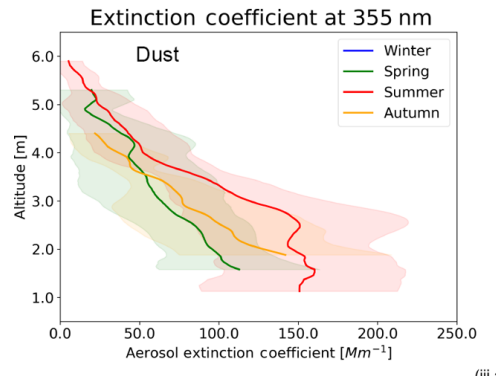

(iii.a)
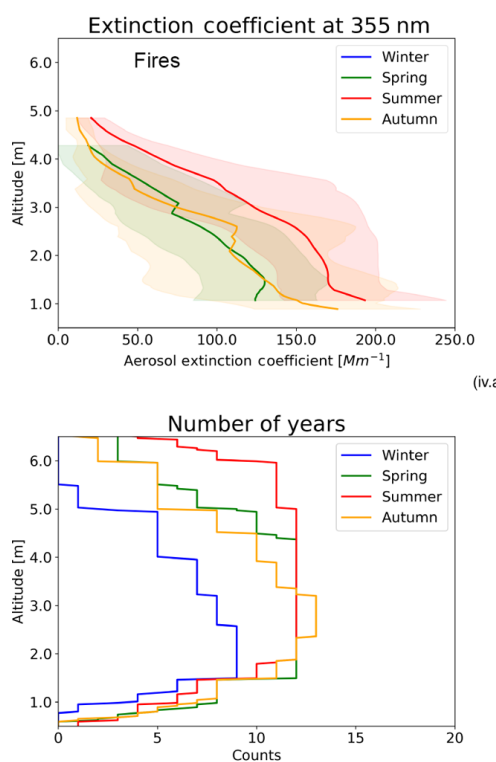
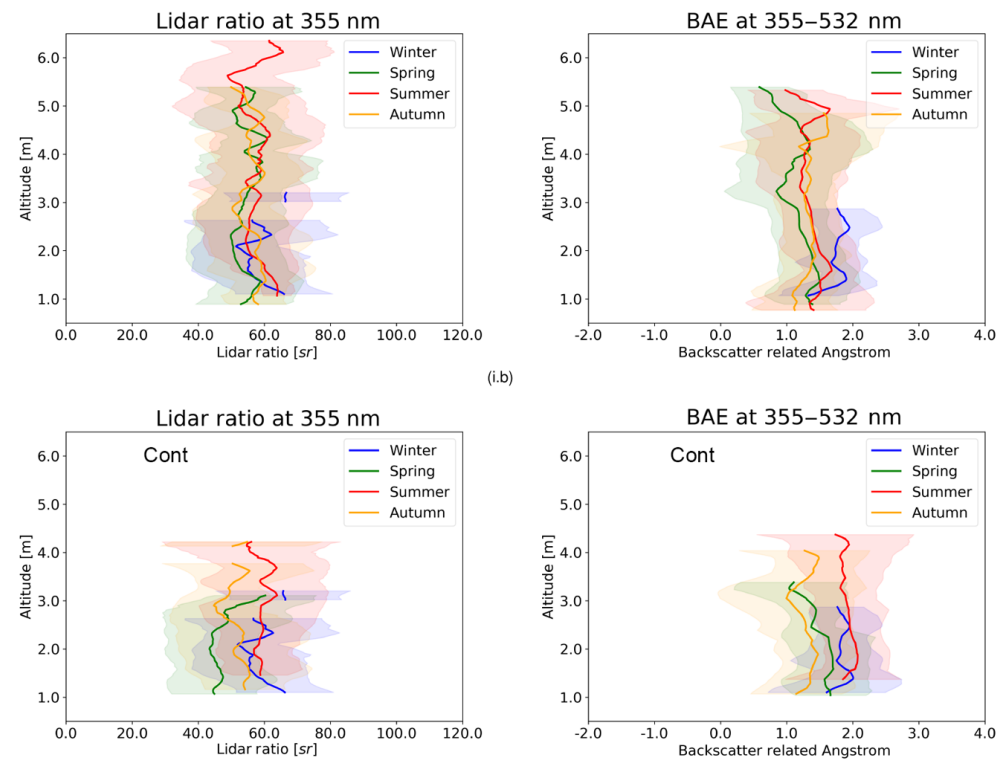

(ii.b)
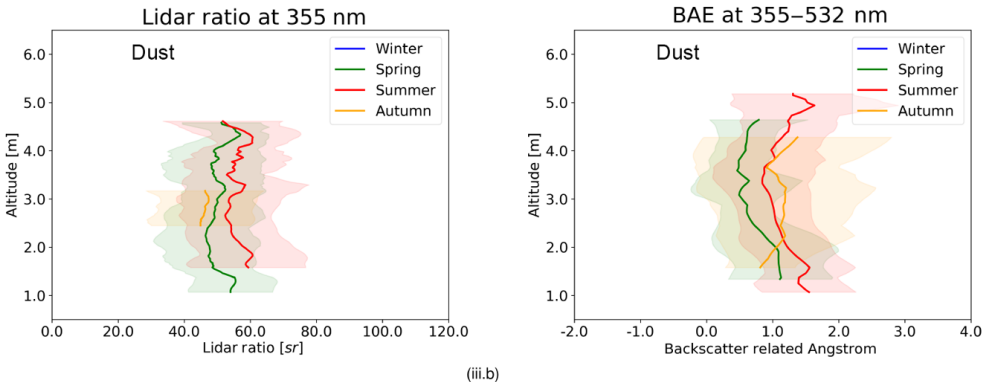

(iii.b)
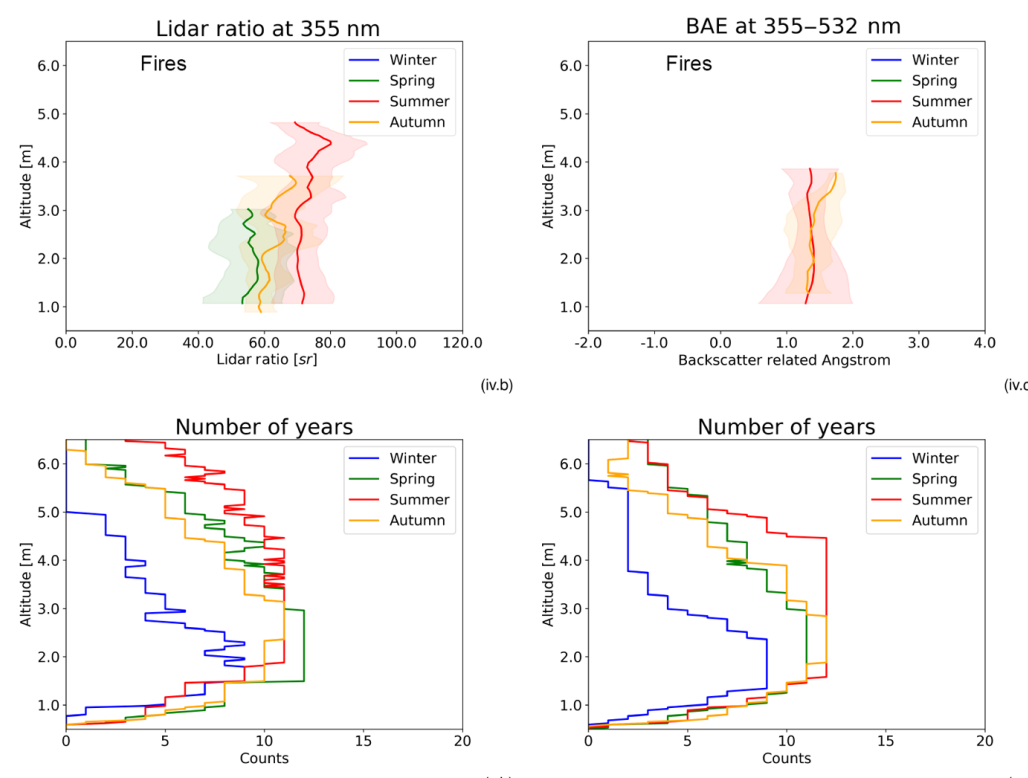

Figure 5. Seasonal profiles of the main aerosol optical properties under study. Rows (i), (ii), (iii), and (iv) correspond to the measurement categories "all", "continental", "dust mixtures", and "biomass mixtures" (see Sect. 4.2.2), respectively, while row (v) corresponds to the number of measurements profiles of the category "all". The profiles of the extinction coefficient at $355 \mathrm{~nm}$, the lidar ratio at $355 \mathrm{~nm}$ and the BAE at 355-532 nm are presented in columns (a), (b), and (c), respectively. 
Table 2. Mean values and variability of the aerosol optical depth at $3555 \mathrm{~nm}$ in the boundary layer and in the free troposphere. These seasonal values are produced from the respective monthly mean averages.

\begin{tabular}{llcccc}
\hline \multicolumn{5}{c}{ Aerosol optical depth at $355 \mathrm{~nm}$} \\
\hline \multirow{2}{*}{ Season } & Type & All & Cont. & Dust mix. & Biom. mix. \\
\hline \multirow{2}{*}{ Winter } & PBL & $0.14 \pm 0.09$ & $0.14 \pm 0.09$ & - & - \\
& FT & $0.08 \pm 0.02$ & $0.08 \pm 0.02$ & - & - \\
\hline \multirow{2}{*}{ Spring } & PBL & $0.20 \pm 0.09$ & $0.12 \pm 0.05$ & $0.23 \pm 0.08$ & $0.20 \pm 0.10$ \\
& FT & $0.16 \pm 0.07$ & $0.11 \pm 0.05$ & $0.17 \pm 0.08$ & $0.18 \pm 0.11$ \\
\hline \multirow{2}{*}{ Summer } & PBL & $0.30 \pm 0.16$ & $0.28 \pm 0.23$ & $0.31 \pm 0.15$ & $0.24 \pm 0.07$ \\
& FT & $0.30 \pm 0.07$ & $0.27 \pm 0.08$ & $0.29 \pm 0.11$ & $0.39 \pm 0.09$ \\
\hline \multirow{2}{*}{ Autumn } & PBL & $0.18 \pm 0.10$ & $0.16 \pm 0.09$ & $0.31 \pm 0.17$ & $0.23 \pm 0.09$ \\
& FT & $0.15 \pm 0.05$ & $0.12 \pm 0.04$ & $0.28 \pm 0.13$ & $0.21 \pm 0.12$ \\
\hline
\end{tabular}

Table 3. Mean columnar values and variability of the lidar ratio at $355 \mathrm{~nm}$ in the boundary layer and in the free troposphere. These seasonal values are produced from the respective monthly mean averages.

\begin{tabular}{llrrrr}
\hline \multicolumn{6}{c}{ Lidar ratio at 355 nm [sr] } \\
\hline \multirow{2}{*}{ Season } & Type & All & Cont. & Dust mix. & Biom. mix. \\
\hline \multirow{2}{*}{ Winter } & PBL & $55 \pm 19$ & $56 \pm 19$ & - & - \\
& FT & $57 \pm 21$ & $57 \pm 21$ & - & - \\
\hline \multirow{2}{*}{ Spring } & PBL & $49 \pm 11$ & $47 \pm 14$ & $47 \pm 13$ & $51 \pm 12$ \\
& FT & $51 \pm 12$ & $46 \pm 11$ & $47 \pm 13$ & $61 \pm 10$ \\
\hline \multirow{2}{*}{ Summer } & PBL & $61 \pm 9$ & $60 \pm 15$ & $60 \pm 14$ & $73 \pm 10$ \\
& FT & $61 \pm 9$ & $61 \pm 15$ & $61 \pm 21$ & $71 \pm 7$ \\
\hline \multirow{2}{*}{ Autumn } & PBL & $53 \pm 17$ & $51 \pm 21$ & $45 \pm 13$ & $59 \pm 4$ \\
& FT & $57 \pm 16$ & $58 \pm 26$ & $48 \pm 15$ & $61 \pm 5$ \\
\hline
\end{tabular}

along the trajectory path is examined using fire pixel data from the MODIS Terra and Aqua Global Monthly Fire Location Product (MCD14ML). The presence of dust particles for trajectories passing over the Sahara is cross-checked using model simulations from the Dust Regional Atmospheric Model (BSC-DREAM8b). Even one transported layer in a profile is enough to flag the measurement. Consequently, the dust mixture and biomass mixture profiles are seldom pure. They are expected to be mixed with continental aerosol, especially near the ground, where the local particles are more dominant. Another type of special event that is available in the database is the volcanic category. For Thessaloniki, this mainly includes some cases of transported volcanic ash during April and May 2010, when the Eyjafjallajökull volcano erupted in Iceland (Pappalardo et al., 2013). These volcanic cases have not been included in a separate mixture category since this type of aerosol mixture is too rare.

\subsubsection{All cases}

The aerosol extinction coefficient at $355 \mathrm{~nm}$ is maximum in summer and minimum in winter (Fig. 5.i.a) for the category "all". The AOD at $355 \mathrm{~nm}$ reaches 0.30 both in the PBL and in the FT during summer (Table 2). In winter, those values decrease to 0.14 and 0.08 , respectively. The lidar ratio ranges mostly between 49 and $61 \mathrm{sr}$ (Table 3 ) for this category. The minimum values appear during spring, and the maximum during summer. The BAE, on the other hand, ranges mostly from 1.0 to 1.7, and the biggest particles tend to appear during autumn and spring in the PBL, while the smallest ones appear during winter in both atmospheric regions (Table 4).

\subsubsection{Continental}

When the dust and biomass burning episodes are excluded ("cont" category), the extinction profile of spring decreases down to the winter levels (Fig. 5.ii.a). The spring AOD drops from 0.20 and 0.16 to 0.12 and 0.11 in the PBL and in the FT, respectively (Table 3). The other seasons are not affected as much. The lidar ratio ranges from 47 to $61 \mathrm{sr}$ (Table 4). Giannakaki et al. (2010) report an annual mean value of $56 \pm 23 \mathrm{sr}$ for the continental polluted particles in Thessaloniki during the period 2001-2007. This comparison, however, is not completely straightforward for the con- 
Table 4. Mean columnar values and variability of the backscatter-related Ångström exponent (BAE) at 355-532 nm in the boundary layer and in the free troposphere. These seasonal values are produced from the respective monthly mean averages.

\begin{tabular}{llcccc}
\hline \multicolumn{6}{c}{ BAE at 355-532 nm } \\
\hline Season & Type & All & Cont. & Dust mix. & Biom. mix. \\
\hline \multirow{2}{*}{ Winter } & PBL & $1.6 \pm 0.6$ & $1.7 \pm 0.6$ & - & - \\
& FT & $1.7 \pm 0.3$ & $1.8 \pm 0.6$ & - & - \\
\hline \multirow{2}{*}{ Spring } & PBL & $1.2 \pm 0.8$ & $1.7 \pm 0.4$ & $1.0 \pm 0.9$ & - \\
& FT & $1.4 \pm 0.5$ & $1.7 \pm 0.7$ & $0.9 \pm 0.6$ & - \\
\hline \multirow{2}{*}{ Summer } & PBL & $1.5 \pm 0.6$ & $1.8 \pm 0.6$ & $1.6 \pm 0.5$ & $1.3 \pm 0.8$ \\
& FT & $1.3 \pm 0.4$ & $1.9 \pm 0.5$ & $1.2 \pm 0.6$ & $1.4 \pm 0.3$ \\
\hline \multirow{2}{*}{ Autumn } & PBL & $1.0 \pm 1.0$ & $0.9 \pm 1.1$ & $1.0 \pm 0.7$ & $1.4 \pm 0.4$ \\
& FT & $1.3 \pm 0.5$ & $1.1 \pm 0.8$ & $1.5 \pm 0.6$ & $1.4 \pm 0.2$ \\
\hline
\end{tabular}

tinental particles, since in their study they divide them into three subcategories (local, continental polluted, and continental west/northwest) based on the wind direction. This is not performed here. The minimum values at $46 \mathrm{sr}$ appear in spring. This could be attributed to mixing with maritime aerosol. It is within the range that Burton et al. (2012) report for polluted maritime particles. The other seasons are within the range that Burton et al. (2012) report for urban particles. Autumn and winter exhibit the highest variability. The BAE values range between 1.7 and 1.9 for all seasons except autumn (Table 5). The minimum values are observed at 0.9 during autumn in the PBL. According to Heese et al. (2017), lower Ångström values are more typical of pollution mixtures rather than of pure pollution. Giannakaki et al. (2010) report an annual mean value of $1.4 \pm 1.0$ for the continental polluted aerosol.

\subsubsection{Dust mixtures}

As far as the dust mixture group is concerned, the maximum values in the extinction profiles at $355 \mathrm{~nm}$ appear in summer above $1.5 \mathrm{~km}$. High values also appear in autumn in the near range (Fig. 5.iii.a). The AOD values range from 0.17 to 0.31 (Table 2). Unfortunately, the winter extinction profile is missing, since the dust cases are rare during this season in Thessaloniki. The autumn data availability is also marginal. The lidar ratio at $355 \mathrm{~nm}$ ranges from 47 to $61 \mathrm{sr}$ (Table 3). Giannakaki et al. (2010) report an annual value of $52 \pm 18 \mathrm{sr}$. The minimum values occur during spring and during autumn in the PBL, ranging from 45 to 48 sr. These values are typical of dust and marine mixtures (Groß et al., 2015; Mona et al., 2006). The summer values at 60 and $61 \mathrm{sr}$ in the PBL and in the FT, respectively, seem closer to the expected values for transported dust (Groß et al., 2015). It is possible that the wind circulation is responsible for this behavior. Due to a high-pressure system over the Balkans that occurs typically from May to September (Tyrlis and Lelieveld, 2013), it is more difficult for the dust layers to be transported directly from northwestern Africa to Thessaloniki through southwest winds that pass over the Mediterranean. Consequently, the dust particles are forced to travel a longer path, through central Europe, in order to reach Thessaloniki (Israelevich et al., 2012). This behavior could result in the different mean lidar ratios between summer and the other two seasons. The BAE ranges mostly between 0.9 and 1.2 (Table 4), values that are typical of dust mixture (Papayannis et al., 2009; Baars et al., 2016). Giannakaki et al. (2010) report an annual BAE value of $1.5 \pm 1.0 \mathrm{sr}$ for this category. A summer BAE of 1.6 in the PBL versus 1.2 in the FT indicates that, in the PBL, the particles are either quite mixed or absent. In the FT the dust component can still be considered dominant, since the BAE is shifted towards values closer to the transported-dust Ångström of $0.5 \pm 0.5$ reported within EARLINET (Müller et al., 2007). Indeed, Marinou et al. (2017) show that the dust component during the transportation episodes over Greece in summer (JAS) is more dominant above $2 \mathrm{~km}$, which is consistent with our findings.

\subsubsection{Biomass burning mixtures}

The main source of biomass burning aerosol for Thessaloniki is agricultural fires in the Balkans, Belarus, and European Russia, which typically begin after March and end in October (McCarty et al., 2017; Amiridis et al., 2009). These mixtures exhibit vertical distributions with maximum values during summer. Below $1 \mathrm{~km}$, the spring and autumn profiles are quite similar. The AOD at $355 \mathrm{~nm}$ generally ranges from 0.18 to 0.24 with the exception of summer in the FT, where the largest AOD value of Table 3 occurs: 0.39. It is possible that the strong biomass burning events tend to occur during summer, and the smoke aerosols are usually transported at higher altitudes. Winter is entirely missing here as well, since the weather conditions are unfavorable for fires. The lidar ratio ranges from 51 to $73 \mathrm{sr}$. The highest values, above $70 \mathrm{sr}$, appear during summer, while the minimum lidar ratio is observed in the PBL during spring. It is close to the respective 

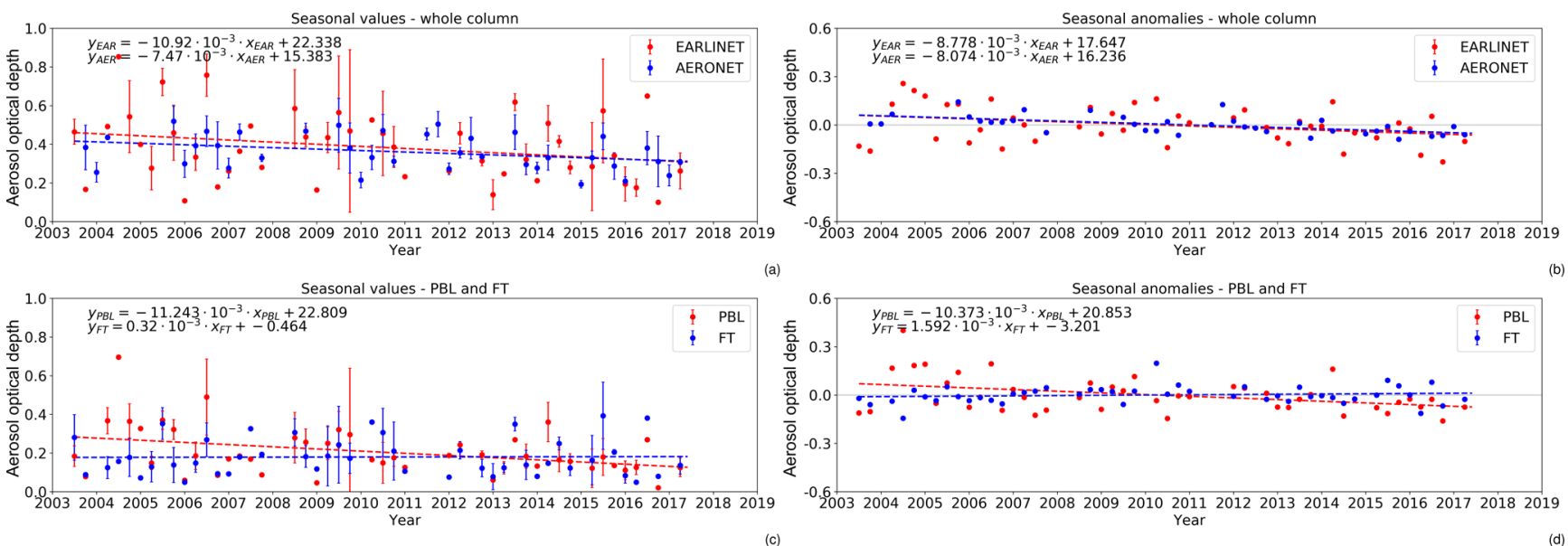

Figure 6. Time series of the seasonal mean AOD values at $355 \mathrm{~nm}$ (a) and of the respective seasonal anomalies (b) that are produced after removing the seasonality for the whole column. The AERONET dataset is displayed along the EARLINET dataset for (a) and (b). Similar time series from the EARLINET dataset AOD in the PBL and in the FT are presented in (c) and (d) for the mean values and the anomalies, respectively. The linear fit line is also included in the figures. For (b) and (d) it represents the trend of AOD at $355 \mathrm{~nm}$ in the period 2003-2017.

continental lidar ratio and also within the range that Heese et al. (2017) report for pollution particles. Consequently, it is quite possible that the biomass layers affect the boundary layer less during spring, if at all. In all other cases, the lidar ratio is similar, ranging from 59 to 61 sr. Differences with the summer levels could be attributed to different aerosol transportation paths and thus either more mixing with continental particles or different aging of smoke (e.g., Amiridis et al., 2009; Nicolae et al., 2013; Papayannis et al., 2014). The BAE values are available only for summer and autumn, ranging from 1.3 to 1.4. Giannakaki et al. (2010) report an annual mean lidar ratio of $69 \pm 17 \mathrm{sr}$ and a mean BAE of $1.7 \pm 0.7$ for this category, which seem consistent with our results.

\subsection{Long-term changes}

The AOD at $355 \mathrm{~nm}$ is selected for the time series analysis, since it is the product with the longest data span for both the EARLINET and the AERONET datasets. The two time series of seasonal averages are shown in Fig. 6a. The lidar AOD values cover a larger range and show higher variability than the sunphotometer values. This is expected given the much lower data availability in this dataset. We intend to compare the two time series in terms of trends and not point by point. The linear fit slope values seem consistent for the two time series. The EARLINET dataset results in a decrease of the AOD by 0.0109 per year, while the sunphotometer dataset results in a decrease of 0.0075 per year. This translates to a decrease per decade of 29.0 and $20.7 \%$, respectively, compared to the AOD levels in 2003. In order to calculate the long-term trend during the period 2003-2017, the seasonality must be removed from the time series. This is performed by subtracting the respective seasonal annual cycle from each year for both datasets. The resulting values are the seasonal AOD anomalies. These time series are presented in Fig. 6b. The least-squares fit slope here represents the dataset trend. The new values are $-0.0088(23.2 \%)$ and -0.0081 (22.3\%) in the period 2003-2017 for the EARLINET and the AERONET datasets, respectively. Fountoulakis et al. (2016) report a negative AOD $320 \mathrm{~nm}$ trend of -0.009 per year for Thessaloniki during the period 1994-2014, a result that seems consistent with our findings. We have applied a MannKendall non-parametric test in order to ensure the existence of these trends (Hirsch et al., 1982; Gilbert, 1987). Both of them are statistically significant at the $95 \%$ confidence interval. We further investigate this decreasing trend by looking at the AOD time series in the PBL and in the FT that are available for the EARLINET dataset. The two products are directly compared in Fig. 6c, and their seasonal anomalies are presented in Fig. 6d. It appears that the free-tropospheric AOD slightly increases by 0.0016 per year; however this trend is not statistically significant at the $95 \%$ confidence interval. The PBL AOD, on the other hand, shows a decreasing statistically significant trend of -0.0104 per year. Consequently, the decrease of the total AOD seems to occur mainly in the lower atmospheric layers, inside the PBL. This could be attributed to a reduction of the aerosol load coming from local sources. A change in the aerosol type, such as a shift to less absorptive particles in the PBL, could also be responsible for this behavior (Fountoulakis et al., 2016). Further research on the aerosol microphysical properties could contribute to gaining insight into this matter. 


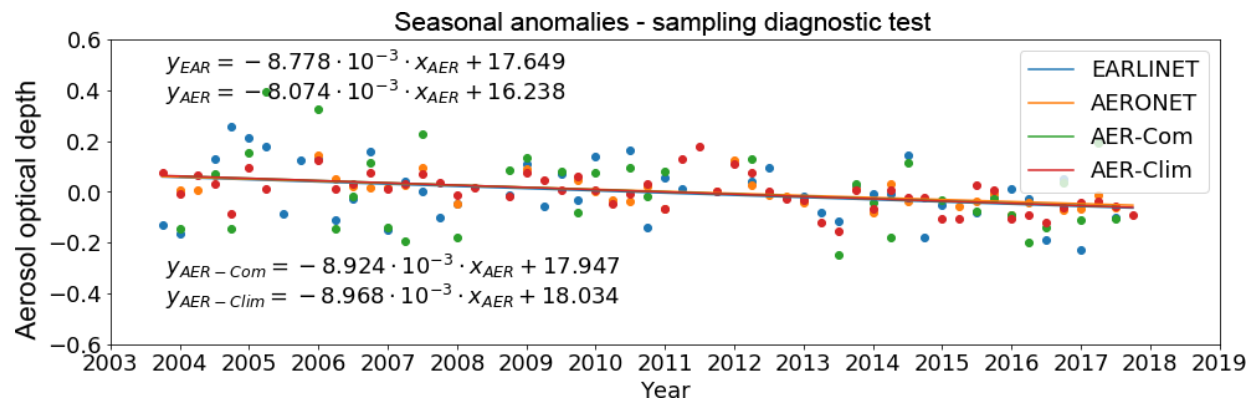

Figure 7. Time series of the seasonal AOD anomalies at $355 \mathrm{~nm}$. The original EARLINET time series is marked with blue, and the original AERONET time series with orange. Two different sampling tests are performed on the AERONET dataset. The "AER-Clim" time series contains only Monday and Thursday measurements and is marked with red, while the "AER-Com" time series contains only common lidar and sunphotometer cases and is marked with green.

\subsection{Factors affecting the compatibility of the two climatologies}

In this section, we present some diagnostic tests that have been performed in order to ensure that the two climatologies can be safely compared despite the different sampling and the non-simultaneous acquisition of measurements. In Sect. 4.5.1, periodical systematic biases that could affect the annual cycles are discussed. Non-periodical biases that could interfere with the long-term trends are addressed in Sect. 4.5.2. Finally, Sect. 4.5.3 includes an analysis of issues that arise due to the different sampling rate between the lidar and the sunphotometer.

\subsection{Seasonal systematic biases}

Since the sunphotometer measurements are performed during the day and the lidar Raman measurements during the night, a systematic bias could be introduced due to daily cycles of emission and meteorology. Additionally, the lidar profiles seldom extend below $600 \mathrm{~m}$. This could also contribute to a systematic bias. This bias is expected to produce an offset and/or seasonal discrepancies between the two datasets. For the purpose of investigating the aforementioned issues, the common daily averages between the two datasets are isolated in order to ensure that only the overlap issues and the daynight discrepancies contribute to the bias. We have computed the AOD at $355 \mathrm{~nm}$ biases by subtracting the sunphotometer daily mean AOD from the lidar daily mean AOD per case. The seasonal biases and the total bias are calculated with a methodology similar to the one applied to the lidar measurements (see Sect. 3.5). The daily means are calculated first. Then the monthly means for each year are calculated by averaging the daily means, and the seasonal means are produced by averaging the monthly mean values. Spring and autumn biases are close to zero, with values at 0.03 and -0.01 , respectively. The winter seasonal bias is -0.15 , while the summer bias is 0.13 . The total bias is close to zero, at -0.003 . Consequently, there is a minor offset towards slightly lower lidar AOD values between the two annual cycles and a systematic estimation of higher lidar AOD values in summer and lower lidar AOD values in winter. This behavior is already visible in the monthly annual cycles (Fig. 4), especially for summer.

\subsection{Non-periodical systematic biases}

As far as the long-term trend analysis is concerned, even if the sunphotometer and the lidar AOD exhibit different seasonal patterns, the trend values should not be much affected since the seasonality has been removed from each time series individually (see Sect. 4.4). Furthermore, an artificial trend could also be introduced to the lidar time series if the bias is non-periodically time-dependent. Changes in the system's full overlap height (see Sect. 2.2) within the time series could produce such an effect. We examine such effects by calculating the trend of the seasonal bias after removing the bias seasonality. The deseasonalized bias exhibits a negative trend of 0.0022 per year; however, it is not significant. As a result, the long-term trend of the lidar AOD is not significantly affected by systematic biases.

\subsection{Sampling}

Another issue that needs to be addressed is that the sparse EARLINET sampling could result in averages that are not representative and comparable to the AERONET ones. This would significantly affect the annual cycle and trends. We limited the AERONET dataset to only Monday and Thursday measurements to be compatible with the EARLINET schedule of nighttime measurements. The resulting significant trend is -0.0090 per year, very close to -0.0085 , which occurs when using the whole dataset (Fig. 7). The annual cycle seems stable, with absolute differences smaller than 0.08 for every monthly average. To be on the safe side, we obtained the sunphotometer trend using only the daily means where both a sunphotometer and a lidar measurement were available. The resulting significant trend is -0.0089 per year 
(Fig. 7), still close to -0.0085 , which occurs when using the whole dataset. Consequently, the lidar averages should be statistically meaningful, and the uncertainty in the EARLINET trend should be less than \pm 0.0005 due to the limited sampling. Probably the length of the time series (14 years) compensates for the sparse sampling rate. In the future, we plan to further analyze how the sampling and the time series length affect the climatological products produced from the columnar aerosol optical properties.

\section{Conclusions}

The analysis resulted in consistent, statistically significant, and decreasing seasonal trends of AOD at $355 \mathrm{~nm}$ of -23.2 and $-22.3 \%$ per decade in the period 2003-2017 over Thessaloniki for the EARLINET and the AERONET datasets, respectively. This implies that the EARLINET schedule of data acquisition can be quite effective in producing data that can be applied to climatological studies. Furthermore, the decreasing trend observed is mainly attributed to changes in the aerosol properties inside the boundary layer. The freetropospheric AOD, on the other hand, does not change much in the period under study, and this change is also not statistically significant. This behavior could be attributed to changes either in the local emissions or in the aerosol type inside the PBL. Further investigation is required on this, however. Concerning the seasonal profiles of the period 2003-2017, the highest values of the extinction at $355 \mathrm{~nm}$ appear during summer, while the lowest ones appear during winter. The mean lidar ratio ranges between 47 and $61 \mathrm{sr}$ for the continental particles. Mixing with Saharan dust and biomass burning aerosol is rare during winter. The dust component is more dominant in the FT than in the PBL during summer. This behavior is supported by other studies. In spring and autumn, the lidar ratio is approximately $47 \mathrm{sr}$, which is more typical of dust and marine mixtures. Concerning the biomass burning cases, the transported layers tend to arrive in the FT during spring and summer. Lidar ratio values close to $60 \mathrm{sr}$ are observed during autumn and during spring in the free troposphere. It increases to approximately $72 \mathrm{sr}$ in summer, which could be the result of different smoke aging caused by different wind circulation paths. Such seasonal profiles of the most dominant aerosol types can be quite useful for applications that require a priori aerosol profiles; for example, they can be utilized in models that require an aerosol climatology as input, in the development of algorithms for satellite products, and in passive remote-sensing techniques that require the information of the aerosol vertical distribution. Future studies that focus on the climatological circulation patterns of the air masses that arrive in Thessaloniki will reveal more information on the seasonal variations of the aerosol properties that are observed and discussed here.
Data availability. The lidar data used in this study are available upon registration at http://data.earlinet.org. The AERONET sunphotometer data for Thessaloniki are publicly available at https: //aeronet.gsfc.nasa.gov/.

Author contributions. DB, VA, EG, NS, MF, and KAV performed and processed lidar measurments of the time series 2003-2017. All of them also participated in the maintenance and calibration of the lidar system throughout these years. AP and DB designed the original lidar system of Thessaloniki. NS developed the processing algorithm that generated the climatological products and prepared the figures. KF developed and reviewed parts of the algorithm concerning the statistical methods applied on the climatological analysis. DB is the PI of the lidar station and directed the preparation of the manuscript. NS prepared the manuscript with contributions from all co-authors.

Competing interests. The authors declare that they have no conflict of interest.

Acknowledgements. This work has been conducted in the framework of EARLINET (EVR1 CT1999-40003), EARLINETASOS (RICA-025991), ACTRIS, and ACTRIS-2 funded by the European Commission. The research leading to these results has received funding from the European Union's Horizon 2020 research and innovation program under grant agreement no. 654109 and previously from the European Union Seventh Framework Programme (FP7/2007-2013) under grant agreement no. 262254. Elina Giannakaki acknowledges the support of the Academy of Finland (project no. 270108). Kalliopi A. Voudouri acknowledges the support of the General Secretariat for Research and Technology (GSRT) and the Hellenic Foundation for Research and Innovation (HFRI). Konstantinos Fragkos would like to acknowledge the support from the European Union's Horizon 2020 research and innovation program under grant agreement no. 692014 - ECARS. This research has been co-financed, via a program of the State Scholarships Foundation (IKY), by the European Union (European Social Fund - ESF) and Greek national funds through the action entitled "Scholarships programme for postgraduates studies - 2nd Study Cycle - in the framework of the Operational Programme - Human Resources Development Program, Education and Lifelong Learning" of the National Strategic Reference Framework (NSRF) 2014-2020.

Edited by: Eduardo Landulfo

Reviewed by: two anonymous referees

\section{References}

Amiridis, V., Balis, D. S., Kazadzis, S., Bais, A., Giannakaki, E., Papayannis, A., and Zerefos, C.: Four-year aerosol observations with a Raman lidar at Thessaloniki, Greece, in the framework of European Aerosol Research Lidar Network (EARLINET), J. Geophys. Res.-Atmos., 110, D21203, https://doi.org/10.1029/2005JD006190, 2005. 
Amiridis, V., Balis, D. S., Giannakaki, E., Stohl, A., Kazadzis, S., Koukouli, M. E., and Zanis, P.: Optical characteristics of biomass burning aerosols over Southeastern Europe determined from UVRaman lidar measurements, Atmos. Chem. Phys., 9, 2431-2440, https://doi.org/10.5194/acp-9-2431-2009, 2009.

Ansmann, A., Wandinger, U., Riebesell, M., Weitkamp, C., and Michaelis, W.: Independent measurement of extinction and backscatter profiles in cirrus clouds by using a combined Raman elastic-backscatter lidar, Appl. Opt., 31, 7113-7131, https://doi.org/10.1364/AO.31.007113, 1992.

Baars, H., Ansmann, A., Engelmann, R., and Althausen, D.: Continuous monitoring of the boundary-layer top with lidar, Atmos. Chem. Phys., 8, 7281-7296, https://doi.org/10.5194/acp-8-72812008, 2008.

Baars, H., Kanitz, T., Engelmann, R., Althausen, D., Heese, B., Komppula, M., Preißler, J., Tesche, M., Ansmann, A., Wandinger, U., Lim, J.-H., Ahn, J. Y., Stachlewska, I. S., Amiridis, V., Marinou, E., Seifert, P., Hofer, J., Skupin, A., Schneider, F., Bohlmann, S., Foth, A., Bley, S., Pfüller, A., Giannakaki, E., Lihavainen, H., Viisanen, Y., Hooda, R. K., Pereira, S. N., Bortoli, D., Wagner, F., Mattis, I., Janicka, L., Markowicz, K. M., Achtert, P., Artaxo, P., Pauliquevis, T., Souza, R. A. F., Sharma, V. P., van Zyl, P. G., Beukes, J. P., Sun, J., Rohwer, E. G., Deng, R., Mamouri, R.-E., and Zamorano, F.: An overview of the first decade of PollyNET: an emerging network of automated Raman-polarization lidars for continuous aerosol profiling, Atmos. Chem. Phys., 16, 5111-5137, https://doi.org/10.5194/acp16-5111-2016, 2016.

Balis, D., Koukouli, M.-E., Siomos, N., Dimopoulos, S., Mona, L., Pappalardo, G., Marenco, F., Clarisse, L., Ventress, L. J., Carboni, E., Grainger, R. G., Wang, P., Tilstra, G., van der A, R., Theys, N., and Zehner, C.: Validation of ash optical depth and layer height retrieved from passive satellite sensors using EARLINET and airborne lidar data: the case of the Eyjafjallajökull eruption, Atmos. Chem. Phys., 16, 5705-5720, https://doi.org/10.5194/acp-16-5705-2016, 2016.

Binietoglou, I., Basart, S., Alados-Arboledas, L., Amiridis, V., Argyrouli, A., Baars, H., Baldasano, J. M., Balis, D., Belegante, L., Bravo-Aranda, J. A., Burlizzi, P., Carrasco, V., Chaikovsky, A., Comerón, A., D’Amico, G., Filioglou, M., Granados-Muñoz, M. J., Guerrero-Rascado, J. L., Ilic, L., Kokkalis, P., Maurizi, A., Mona, L., Monti, F., Muñoz Porcar, C., Nicolae, D., Papayannis, A., Pappalardo, G., Pejanovic, G., Pereira, S. N., Perrone, M. R., Pietruczuk, A., Posyniak, M., Rocadenbosch, F., Rodríguez-Gómez, A., Sicard, M., Siomos, N., Szkop, A., Terradellas, E., Tsekeri, A., Vukovic, A., Wandinger, U., and Wagner, J.: A methodology for investigating dust model performance using synergistic EARLINET/AERONET dust concentration retrievals, Atmos. Meas. Tech., 8, 3577-3600, https://doi.org/10.5194/amt-8-3577-2015, 2015.

Böckmann, C., Wandinger, U., Ansmann, A., Bösenberg, J., Amiridis, V., Boselli, A., Delaval, A., Tomasi, F. D., Frioud, M., Grigorov, I. V., Hågård, A., Horvat, M., Iarlori, M., Komguem, L., Kreipl, S., Larchevêque, G., Matthias, V., Papayannis, A., Pappalardo, G., Rocadenbosch, F., Rodrigues, J. A., Schneider, J., Shcherbakov, V., and Wiegner, M.: Aerosol lidar intercomparison in the framework of the EARLINET project. 2.Aerosol backscatter algorithms, Appl. Opt., 43, 977-989, https://doi.org/10.1364/AO.43.000977, 2004.
Bravo-Aranda, J. A., de Arruda Moreira, G., Navas-Guzmán, F., Granados-Muñoz, M. J., Guerrero-Rascado, J. L., PozoVázquez, D., Arbizu-Barrena, C., Olmo Reyes, F. J., Mallet, M., and Alados Arboledas, L.: A new methodology for PBL height estimations based on lidar depolarization measurements: analysis and comparison against MWR and WRF model-based results, Atmos. Chem. Phys., 17, 6839-6851, https://doi.org/10.5194/acp-17-6839-2017, 2017.

Brenot, H., Theys, N., Clarisse, L., van Geffen, J., van Gent, J., Van Roozendael, M., van der A, R., Hurtmans, D., Coheur, P.-F., Clerbaux, C., Valks, P., Hedelt, P., Prata, F., Rasson, O., Sievers, K., and Zehner, C.: Support to Aviation Control Service (SACS): an online service for near-real-time satellite monitoring of volcanic plumes, Nat. Hazards Earth Syst. Sci., 14, 1099-1123, https://doi.org/10.5194/nhess-14-1099-2014, 2014.

Brooks, I. M.: Finding Boundary Layer Top: Application of a Wavelet Covariance Transform to Lidar Backscatter Profiles, J. Atmos. Ocean. Tech., 20, 1092-1105, https://doi.org/10.1175/15200426(2003)020<1092:FBLTAO>2.0.CO;2, 2003.

Burton, S. P., Ferrare, R. A., Hostetler, C. A., Hair, J. W., Rogers, R. R., Obland, M. D., Butler, C. F., Cook, A. L., Harper, D. B., and Froyd, K. D.: Aerosol classification using airborne High Spectral Resolution Lidar measurements methodology and examples, Atmos. Meas. Tech., 5, 73-98, https://doi.org/10.5194/amt-5-73-2012, 2012.

Chaikovsky, A., Dubovik, O., Holben, B., Bril, A., Goloub, P., Tanré, D., Pappalardo, G., Wandinger, U., Chaikovskaya, L., Denisov, S., Grudo, J., Lopatin, A., Karol, Y., Lapyonok, T., Amiridis, V., Ansmann, A., Apituley, A., Allados-Arboledas, L., Binietoglou, I., Boselli, A., D’Amico, G., Freudenthaler, V., Giles, D., Granados-Muñoz, M. J., Kokkalis, P., Nicolae, D., Oshchepkov, S., Papayannis, A., Perrone, M. R., Pietruczuk, A., Rocadenbosch, F., Sicard, M., Slutsker, I., Talianu, C., De Tomasi, F., Tsekeri, A., Wagner, J., and Wang, X.: Lidar-Radiometer Inversion Code (LIRIC) for the retrieval of vertical aerosol properties from combined lidar/radiometer data: development and distribution in EARLINET, Atmos. Meas. Tech., 9, 1181-1205, https://doi.org/10.5194/amt-9-1181-2016, 2016.

Dubovik, O. and King, M. D.: A flexible inversion algorithm for retrieval of aerosol optical properties from Sun and sky radiance measurements, J. Geophys. Res.-Atmos., 105, 20673-20696, https://doi.org/10.1029/2000JD900282, 2000.

Dubovik, O., Sinyuk, A., Lapyonok, T., Holben, B. N., Mishchenko, M., Yang, P., Eck, T. F., Volten, H., Muñoz, O., Veihelmann, B., van der Zande, W. J., Leon, J.-F., Sorokin, M., and Slutsker, I.: Application of spheroid models to account for aerosol particle nonsphericity in remote sensing of desert dust, J. Geophys. Res.Atmos., 111, D11208, https://doi.org/10.1029/2005JD006619, 2006.

EARLINET database: lidar data, available at: http://data.earlinet. org, last access: 25 July 2018.

Fernald, F. G.: Analysis of atmospheric lidar observations: some comments, Appl. Opt., 23, 652-653, https://doi.org/10.1364/AO.23.000652, 1984.

Flamant, C., Pelon, J., Flamant, P. H., and Durand, P.: Lidar determination of the entrainment zone thickness at the top of the unstable marine atmospheric boundary layer, Bound.-Layer Me- 
teorol., 83, 247-284, https://doi.org/10.1023/A:1000258318944, 1997.

Fountoulakis, I., Bais, A. F., Fragkos, K., Meleti, C., Tourpali, K., and Zempila, M. M.: Short- and long-term variability of spectral solar UV irradiance at Thessaloniki, Greece: effects of changes in aerosols, total ozone and clouds, Atmos. Chem. Phys., 16, 24932505, https://doi.org/10.5194/acp-16-2493-2016, 2016.

Freudenthaler, V., Linné, H., Chaikovski, A., Rabus, D., and Groß, S.: EARLINET lidar quality assurance tools, Atmos. Meas. Tech. Discuss., https://doi.org/10.5194/amt-2017-395, in review, 2018.

Garratt, J.: The atmospheric boundary layer, Cambridge atmospheric and space science serie, Cambridge University Pres, Cambridge, 316 pp., 1992.

Georgoulias, A. K., Papanastasiou, D. K., Melas, D., Amiridis, V., and Alexandri, G.: Statistical analysis of boundary layer heights in a suburban environment, Meteorol. Atmos. Phys., 104, 103111, https://doi.org/10.1007/s00703-009-0021-z, 2009.

Gerstl, S. A. W. and Zardecki, A.: Effects of aerosols on photosynthesis, Nature, 300, 436-437, https://doi.org/10.1038/300436a0, 1982.

Giannakaki, E., Balis, D. S., Amiridis, V., and Zerefos, C.: Optical properties of different aerosol types: seven years of combined Raman-elastic backscatter lidar measurements in Thessaloniki, Greece, Atmos. Meas. Tech., 3, 569-578, https://doi.org/10.5194/amt-3-569-2010, 2010.

Gilbert, R. O.: Statistical methods for environmental pollution monitoring, Van Nostrand Reinhold, New York, NY, 200-239, 1987.

Goddard Space FLight Center: AERONET (AErosol RObotic NETwork), available at: https://aeronet.gsfc.nasa.gov/, last access: 25 July 2018.

Groß, S., Freudenthaler, V., Wirth, M., and Weinzierl, B.: Towards an aerosol classification scheme for future EarthCARE lidar observations and implications for research needs, Atmos. Sci. Lett., 16, 77-82, https://doi.org/10.1002/as12.524, 2015.

Haeffelin, M., Angelini, F., Morille, Y., Martucci, G., Frey, S., Gobbi, G. P., Lolli, S., O’Dowd, C. D., Sauvage, L., XuerefRémy, I., Wastine, B., and Feist, D. G.: Evaluation of MixingHeight Retrievals from Automatic Profiling Lidars and Ceilometers in View of Future Integrated Networks in Europe, Bound.Layer Meteorol., 143, 49-75, https://doi.org/10.1007/s10546011-9643-z, 2012.

Hamill, P., Giordano, M., Ward, C., Giles, D., and Holben, B.: An AERONET-based aerosol classification using the Mahalanobis distance, Atmos. Environ., 140, 213-233, https://doi.org/10.1016/j.atmosenv.2016.06.002, 2016.

Heese, B., Baars, H., Bohlmann, S., Althausen, D., and Deng, R.: Continuous vertical aerosol profiling with a multi-wavelength Raman polarization lidar over the Pearl River Delta, China, Atmos. Chem. Phys., 17, 6679-6691, https://doi.org/10.5194/acp17-6679-2017, 2017.

Herman, J., Evans, R., Cede, A., Abuhassan, N., Petropavlovskikh, I., McConville, G., Miyagawa, K., and Noirot, B.: Ozone comparison between Pandora \#34, Dobson \#061, OMI, and OMPS in Boulder, Colorado, for the period December 2013-December 2016, Atmos. Meas. Tech., 10, 3539-3545, https://doi.org/10.5194/amt-10-3539-2017, 2017.

Hirsch, R. M., Slack, J. R., and Smith, R. A.: Techniques of trend analysis for monthly water qual- ity data, Water Resources Research, 18, 107-121, https://doi.org/10.1029/WR018i001p00107, 1982.

Hirsikko, A., O'Connor, E. J., Komppula, M., Korhonen, K., Pfüller, A., Giannakaki, E., Wood, C. R., Bauer-Pfundstein, M., Poikonen, A., Karppinen, T., Lonka, H., Kurri, M., Heinonen, J., Moisseev, D., Asmi, E., Aaltonen, V., Nordbo, A., Rodriguez, E., Lihavainen, H., Laaksonen, A., Lehtinen, K. E. J., Laurila, T., Petäjä, T., Kulmala, M., and Viisanen, Y.: Observing wind, aerosol particles, cloud and precipitation: Finland's new groundbased remote-sensing network, Atmos. Meas. Tech., 7, 13511375, https://doi.org/10.5194/amt-7-1351-2014, 2014.

Holben, B., Eck, T., Slutsker, I., Tanré, D., Buis, J., Setzer, A., Vermote, E., Reagan, J., Kaufman, Y., Nakajima, T., Lavenu, F., Jankowiak, I., and Smirnov, A.: AERONET - A Federated Instrument Network and Data Archive for Aerosol Characterization, Remote Sens. Environ., 66, 1-16, https://doi.org/10.1016/S0034-4257(98)00031-5, 1998.

Hönninger, G., von Friedeburg, C., and Platt, U.: Multi axis differential optical absorption spectroscopy (MAX-DOAS), Atmos. Chem. Phys., 4, 231-254, https://doi.org/10.5194/acp-4231-2004, 2004.

Israelevich, P., Ganor, E., Alpert, P., Kishcha, P., and Stupp, A.: Predominant transport paths of Saharan dust over the Mediterranean Sea to Europe, J. Geophys. Res.-Atmos., 117, D02205, https://doi.org/10.1029/2011JD016482, 2012.

Kazadzis, S., Bais, A., Amiridis, V., Balis, D., Meleti, C., Kouremeti, N., Zerefos, C. S., Rapsomanikis, S., Petrakakis, M., Kelesis, A., Tzoumaka, P., and Kelektsoglou, K.: Nine years of UV aerosol optical depth measurements at Thessaloniki, Greece, Atmos. Chem. Phys., 7, 2091-2101, https://doi.org/10.5194/acp7-2091-2007, 2007.

Kazadzis, S., Raptis, P., Kouremeti, N., Amiridis, V., Arola, A., Gerasopoulos, E., and Schuster, G. L.: Aerosol absorption retrieval at ultraviolet wavelengths in a complex environment, Atmos. Meas. Tech., 9, 5997-6011, https://doi.org/10.5194/amt-95997-2016, 2016.

Klett, J. D.: Stable analytical inversion solution for processing lidar returns, Appl. Opt., 20, 211-220, https://doi.org/10.1364/AO.20.000211, 1981.

Lolli, S., Delaval, A., Loth, C., Garnier, A., and Flamant, P. H.: 0.355-micrometer direct detection wind lidar under testing during a field campaign in consideration of ESA's ADM-Aeolus mission, Atmos. Meas. Tech., 6, 3349-3358, https://doi.org/10.5194/amt-6-3349-2013, 2013.

Löndahl, J., Swietlicki, E., Lindgren, E., and Loft, S.: Aerosol exposure versus aerosol cooling of climate: what is the optimal emission reduction strategy for human health?, Atmos. Chem. Phys., 10, 9441-9449, https://doi.org/10.5194/acp-109441-2010, 2010.

Lopatin, A., Dubovik, O., Chaikovsky, A., Goloub, P., Lapyonok, T., Tanré, D., and Litvinov, P.: Enhancement of aerosol characterization using synergy of lidar and sun-photometer coincident observations: the GARRLiC algorithm, Atmos. Meas. Tech., 6, 2065-2088, https://doi.org/10.5194/amt-6-2065-2013, 2013.

López-Solano, J., Redondas, A., Carlund, T., Rodriguez-Franco, J. J., Diémoz, H., León-Luis, S. F., Hernández-Cruz, B., GuiradoFuentes, C., Kouremeti, N., Gröbner, J., Kazadzis, S., Carreño, V., Berjón, A., Santana-Díaz, D., Rodríguez-Valido, M., De Bock, V., Moreta, J. R., Rimmer, J., Boulkelia, L., Jepsen, 
N., Eriksen, P., Bais, A. F., Shirotov, V., Vilaplana, J. M., Wilson, K. M., and Karppinen, T.: Aerosol optical depth in the European Brewer Network, Atmos. Chem. Phys., 18, 3885-3902, https://doi.org/10.5194/acp-18-3885-2018, 2018.

Marinou, E., Amiridis, V., Binietoglou, I., Tsikerdekis, A., Solomos, S., Proestakis, E., Konsta, D., Papagiannopoulos, N., Tsekeri, A., Vlastou, G., Zanis, P., Balis, D., Wandinger, U., and Ansmann, A.: Three-dimensional evolution of Saharan dust transport towards Europe based on a 9-year EARLINEToptimized CALIPSO dataset, Atmos. Chem. Phys., 17, 58935919, https://doi.org/10.5194/acp-17-5893-2017, 2017.

Matthias, V., Freudenthaler, V., Amodeo, A., Balin, I., Balis, D., Bösenberg, J., Chaikovsky, A., Chourdakis, G., Comeron, A., Delaval, A., Tomasi, F. D., Eixmann, R., Hågård, A., Komguem, L., Kreipl, S., Matthey, R., Rizi, V., Rodrigues, J. A., Wandinger, U., and Wang, X.: Aerosol lidar intercomparison in the framework of the EARLINET project. 1.Instruments, Appl. Opt., 43, 961-976, https://doi.org/10.1364/AO.43.000961, 2004.

Mauderly, J. L. and Chow, J. C.: Health Effects of Organic Aerosols, Inhalation Toxicology, 20, 257-288, https://doi.org/10.1080/08958370701866008, pMID: 18300047, 2008.

McCarty, J. L., Krylov, A., Prishchepov, A. V., Banach, D. M., Tyukavina, A., Potapov, P., and Turubanova, S.: Agricultural Fires in European Russia, Belarus, and Lithuania and Their Impact on Air Quality, 2002-2012, 193-221, Springer International Publishing, Cham, https://doi.org/10.1007/978-3-31942638-9_9, 2017.

Mehta, S. K., Ratnam, M. V., Sunilkumar, S. V., Rao, D. N., and Krishna Murthy, B. V.: Diurnal variability of the atmospheric boundary layer height over a tropical station in the Indian monsoon region, Atmos. Chem. Phys., 17, 531-549, https://doi.org/10.5194/acp-17-531-2017, 2017.

Menut, L., Flamant, C., Pelon, J., and Flamant, P. H.: Urban boundary-layer height determination from lidar measurements over the Paris area, Appl. Opt., 38, 945-954, https://doi.org/10.1364/AO.38.000945, 1999.

Milroy, C., Martucci, G., Lolli, S., Loaec, S., Sauvage, L., XuerefRemy, I., Lavric, V. J., Ciais, P., Dietrich, G. F., Biavati, G., and O'Dowd, C. D.: An Assessment of Pseudo-Operational GroundBased Light Detection and Ranging Sensors to Determine the Boundary-Layer Structure in the Coastal Atmosphere, Adv. Meteorol., 2012, 929080, https://doi.org/10.1155/2012/929080, 2012.

Mona, L., Amodeo, A., Pandolfi, M., and Pappalardo, G.: Saharan dust intrusions in the Mediterranean area: Three years of Raman lidar measurements, J. Geophys. Res.-Atmos., 111, D16203, https://doi.org/10.1029/2005JD006569, 2006.

Müller, D., Ansmann, A., Mattis, I., Tesche, M., Wandinger, U., Althausen, D., and Pisani, G.: Aerosol-type-dependent lidar ratios observed with Raman lidar, J. Geophys. Res.-Atmos., 112, D16202, https://doi.org/10.1029/2006JD008292, 2007.

Nicolae, D., Nemuc, A., Müller, D., Talianu, C., Vasilescu, J., Belegante, L., and Kolgotin, A.: Characterization of fresh and aged biomass burning events using multiwavelength Raman lidar and mass spectrometry, J. Geophys. Res.-Atmos., 118, 2956-2965, https://doi.org/10.1002/jgrd.50324, 2013.

Papayannis, A., Mamouri, R. E., Amiridis, V., Kazadzis, S., Pérez, C., Tsaknakis, G., Kokkalis, P., and Baldasano, J. M.: Systematic lidar observations of Saharan dust layers over Athens, Greece in the frame of EARLINET project (2004-2006), Ann. Geophys., 27, 3611-3620, https://doi.org/10.5194/angeo-27-36112009, 2009.

Papayannis, A., Nicolae, D., Kokkalis, P., Binietoglou, I., Talianu, C., Belegante, L., Tsaknakis, G., Cazacu, M., Vetres, I., and Ilic, L.: Optical, size and mass properties of mixed type aerosols in Greece and Romania as observed by synergy of lidar and sunphotometers in combination with model simulations: A case study, Sci. Total Environ., 500-501, 277-294, https://doi.org/10.1016/j.scitotenv.2014.08.101, 2014.

Pappalardo, G., Amodeo, A., Pandolfi, M., Wandinger, U., Ansmann, A., Bösenberg, J., Matthias, V., Amiridis, V., Tomasi, F. D., Frioud, M., Iarlori, M., Komguem, L., Papayannis, A., Rocadenbosch, F., and Wang, X.: Aerosol lidar intercomparison in the framework of the EARLINET project. 3. Ramanlidar algorithm for aerosol extinction, backscatter, and lidar ratio, Appl. Opt., 43, 5370-5385, https://doi.org/10.1364/AO.43.005370, 2004.

Pappalardo, G., Wandinger, U., Mona, L., Hiebsch, A., Mattis, I., Amodeo, A., Ansmann, A., Seifert, P., Linné, H., Apituley, A., Alados, A. L., Balis, D., Chaikovsky, A., D’Amico, G., De Tomasi, F., Freudenthaler, V., Giannakaki, E., Giunta, A., Grigorov, I., Iarlori, M., Madonna, F., Mamouri, R., Nasti, L., Papayannis, A., Pietruczuk, A., Pujadas, M., Rizi, V., Rocadenbosch, F., Russo, F., Schnell, F., Spinelli, N., Wang, X., and Wiegner, M.: EARLINET correlative measurements for CALIPSO: First intercomparison results, J. Geophys. Res.Atmos., 115, D00H19, https://doi.org/10.1029/2009JD012147, 2010.

Pappalardo, G., Mona, L., D’Amico, G., Wandinger, U., Adam, M., Amodeo, A., Ansmann, A., Apituley, A., Alados Arboledas, L., Balis, D., Boselli, A., Bravo-Aranda, J. A., Chaikovsky, A., Comeron, A., Cuesta, J., De Tomasi, F., Freudenthaler, V., Gausa, M., Giannakaki, E., Giehl, H., Giunta, A., Grigorov, I., Groß, S., Haeffelin, M., Hiebsch, A., Iarlori, M., Lange, D., Linné, H., Madonna, F., Mattis, I., Mamouri, R.-E., McAuliffe, M. A. P., Mitev, V., Molero, F., Navas-Guzman, F., Nicolae, D., Papayannis, A., Perrone, M. R., Pietras, C., Pietruczuk, A., Pisani, G., Preißler, J., Pujadas, M., Rizi, V., Ruth, A. A., Schmidt, J., Schnell, F., Seifert, P., Serikov, I., Sicard, M., Simeonov, V., Spinelli, N., Stebel, K., Tesche, M., Trickl, T., Wang, X., Wagner, F., Wiegner, M., and Wilson, K. M.: Four-dimensional distribution of the 2010 Eyjafjallajökull volcanic cloud over Europe observed by EARLINET, Atmos. Chem. Phys., 13, 4429-4450, https://doi.org/10.5194/acp-13-4429-2013, 2013.

Pappalardo, G., Amodeo, A., Apituley, A., Comeron, A., Freudenthaler, V., Linné, H., Ansmann, A., Bösenberg, J., D’Amico, G., Mattis, I., Mona, L., Wandinger, U., Amiridis, V., AladosArboledas, L., Nicolae, D., and Wiegner, M.: EARLINET: towards an advanced sustainable European aerosol lidar network, Atmos. Meas. Tech., 7, 2389-2409, https://doi.org/10.5194/amt7-2389-2014, 2014.

Sasano, Y. and Nakane, H.: Significance of the extinction/backscatter ratio and the boundary value term in the solution for the two-component lidar equation, Appl. Opt., 23, 1-13, https://doi.org/10.1364/AO.23.0011_1, 1984.

Schneider, J., Balis, D., Böckmann, C., Bösenberg, J., Calpini, B., Chaikovsky, A., Comeron, A., Flamant, P., Freudenthaler, V., 
Hågård, A., Mattis, I., Mitev, V., Papayannis, A., Pappalardo, G., Pelon, J., Perrone, M., Resendes, D., Spinelli, N., Trickl, T., Vaughan, G., and Visconti, G.: European aerosol research lidar network to establish an aerosol climatology (EARLINET), J. Aerosol Sci., 31, S592-S593, 2000.

Schneider, M., Redondas, A., Hase, F., Guirado, C., Blumenstock, T., and Cuevas, E.: Comparison of ground-based Brewer and FTIR total column $\mathrm{O}_{3}$ monitoring techniques, Atmos. Chem. Phys., 8, 5535-5550, https://doi.org/10.5194/acp-8-5535-2008, 2008.

She, C. Y., Alvarez, R. J., Caldwell, L. M., and Krueger, D. A.: High-spectral-resolution Rayleigh-Mie lidar measurement of aerosol and atmospheric profiles, Opt. Lett., 17, 541-543, https://doi.org/10.1364/OL.17.000541, 1992.

Siomos, N., Balis, D. S., Poupkou, A., Liora, N., Dimopoulos, S., Melas, D., Giannakaki, E., Filioglou, M., Basart, S., and Chaikovsky, A.: Investigating the quality of modeled aerosol profiles based on combined lidar and sunphotometer data, Atmos. Chem. Phys., 17, 7003-7023, https://doi.org/10.5194/acp17-7003-2017, 2017.

Soni, K., Singh, S., Bano, T., Tanwar, R. S., and Nath, S.: Wavelength Dependence of the Aerosol Angstrom Exponent and Its Implications Over Delhi, India, Aerosol Sci. Tech., 45, 14881498, https://doi.org/10.1080/02786826.2011.601774, 2011.

Stefan, K., Declan, O., Philip, S., Silvia, K., Kai, Z., Hauke, S., Sebastian, R., Marco, G., F., E. T., and Bjorn, S.: MAC - v1: A new global aerosol climatology for climate studies, J. Adv. Model. Earth Syst., 5, 704-740, https://doi.org/10.1002/jame.20035, 2013.
Takemura, T., Nakajima, T., Dubovik, O., Holben, B. N., and Kinne, S.: Single-Scattering Albedo and Radiative Forcing of Various Aerosol Species with a Global Three-Dimensional Model, J. Climate, 15, 333-352, https://doi.org/10.1175/15200442(2002)015<0333:SSAARF>2.0.CO;2, 2002.

Tomasi, F. D. and Perrone, M. R.: PBL and dust layer seasonal evolution by lidar and radiosounding measurements over a peninsular site, Atmos. Res., 80, 86-103, https://doi.org/10.1016/j.atmosres.2005.06.010, 2006.

Tyrlis, E. and Lelieveld, J.: Climatology and Dynamics of the Summer Etesian Winds over the Eastern Mediterranean, J. Atmos Sci., 70, 3374-3396, https://doi.org/10.1175/JAS-D-13-035.1, 2013.

Wandinger, U. and Ansmann, A.: Experimental determination of the lidar overlap profile with Raman lidar, Appl. Opt., 41, 511-514, https://doi.org/10.1364/AO.41.000511, 2002.

Welton, E. J., Campbell, J. R., Spinhirne, J. D., and Scott, V. S.: Global monitoring of clouds and aerosols using a network of micropulse lidar systems, Proc. SPIE, 8, 4153, https://doi.org/10.1117/12.417040, 2001.

Winker, D. M., Vaughan, M. A., Omar, A., Hu, Y., Powell, K. A., Liu, Z., Hunt, W. H., and Young, S. A. Overview of the CALIPSO Mission and CALIOP Data Processing Algorithms, J. Atmos. Ocean. Tech., 26, 2310-2323, https://doi.org/10.1175/2009JTECHA1281.1, 2009.

Yiquan, J., Yang, X.-Q., and Xiaohong, L.: Seasonality in anthropogenic aerosol effects on East Asian climate simulated with CAM5, J. Geophys. Res.-Atmos., 120, 10837-10861, https://doi.org/10.1002/2015JD023451, 2015. 